\title{
In situ chemical composition measurement of individual cloud residue particles at a mountain site, southern China
}

\author{
Qinhao Lin ${ }^{1,2}$, Guohua Zhang ${ }^{1}$, Long Peng ${ }^{1,2}$, Xinhui Bi ${ }^{1}$, Xinming Wang ${ }^{1}$, Fred J. Brechtel ${ }^{3}$, Mei Li $^{4}$, \\ Duohong Chen ${ }^{5}$, Ping'an Peng ${ }^{1}$, Guoying Sheng ${ }^{1}$, and Zhen Zhou ${ }^{4}$ \\ ${ }^{1}$ State Key Laboratory of Organic Geochemistry and Guangdong Key Laboratory of Environmental Protection and Resources \\ Utilization, Guangzhou Institute of Geochemistry, Chinese Academy of Sciences, Guangzhou, 510640, China \\ ${ }^{2}$ University of Chinese Academy of Sciences, Beijing, 100049, China \\ ${ }^{3}$ Brechtel Manufacturing Inc., Hayward, 94544, CA, USA \\ ${ }^{4}$ Atmospheric Environment Institute of Safety and Pollution Control, Jinan University, Guangzhou 510632, China \\ ${ }^{5}$ State Environmental Protection Key Laboratory of Regional Air Quality Monitoring, Guangdong Environmental Monitoring \\ Center, Guangzhou 510308, China
}

Correspondence to: Xinhui Bi (bixh@gig.ac.cn)

Received: 10 January 2017 - Discussion started: 14 February 2017

Revised: 10 June 2017 - Accepted: 12 June 2017 - Published: 12 July 2017

\begin{abstract}
To investigate how atmospheric aerosol particles interact with chemical composition of cloud droplets, a ground-based counterflow virtual impactor (GCVI) coupled with a real-time single-particle aerosol mass spectrometer (SPAMS) was used to assess the chemical composition and mixing state of individual cloud residue particles in the Nanling Mountains (1690 ma.s.1.), southern China, in January 2016. The cloud residues were classified into nine particle types: aged elemental carbon (EC), potassium-rich (K-rich), amine, dust, $\mathrm{Pb}, \mathrm{Fe}$, organic carbon (OC), sodiumrich (Na-rich) and "Other". The largest fraction of the total cloud residues was the aged EC type (49.3\%), followed by the K-rich type (33.9\%). Abundant aged EC cloud residues that mixed internally with inorganic salts were found in air masses from northerly polluted areas. The number fraction (NF) of the K-rich cloud residues increased within southwesterly air masses from fire activities in Southeast Asia. When air masses changed from northerly polluted areas to southwesterly ocean and livestock areas, the amine particles increased from 0.2 to $15.1 \%$ of the total cloud residues. The dust, $\mathrm{Fe}, \mathrm{Pb}, \mathrm{Na}$-rich and OC particle types had a low contribution $(0.5-4.1 \%)$ to the total cloud residues. Higher fraction of nitrate (88-89\%) was found in the dust and Na-rich cloud residues relative to sulfate (41-42\%) and ammonium (15-23\%). Higher intensity of nitrate was found in the cloud residues relative to the ambient particles. Compared with
\end{abstract}

nonactivated particles, nitrate intensity decreased in all cloud residues except for dust type. To our knowledge, this study is the first report on in situ observation of the chemical composition and mixing state of individual cloud residue particles in China.

\section{Introduction}

Aerosol-cloud interactions influence the thermodynamic and radiation balance of the atmosphere (Boucher et al., 2013). Anthropogenic particles can increase the number concentration of small cloud droplets, and, in turn, affect reflectivity and lifetime of clouds (Stier et al., 2005; Lohmann et al., 2007; Rosenfeld et al., 2008). In situ cloud chemical measurements have shown varied chemical composition of cloud water or residues in various regions (Sorooshian et al., 2007a; Roth et al., 2016; Li et al., 2017). Despite a large number of aerosol and cloud studies over the past 20 years, the uncertainty for evaluating radiative forcing due to aerosol-cloud interactions has not been reduced (Seinfeld. et al., 2016). Therefore, it is crucial to assess how atmospheric aerosol particles contribute and interact with cloud droplets.

The ability of aerosol particles to act as cloud condensation nuclei $(\mathrm{CCN})$ is dependent on the size and chemical composition of particles at a given supersaturation (Mc- 
Figgans et al., 2006). Wiedensohler et al. (2009) found that the enhancement of particles' $\mathrm{CCN}$ ability was related to an increase in the average sulfate mass concentration. Dusek et al. (2006) demonstrated that CCN behavior was more affected by aerosol size than chemical composition. Meanwhile, aerosol mixing state also play an important role in the ability of aerosol to act as CCN. It has been reported that freshly emitted elemental carbon (EC) particles generally exhibit low CCN activity, whereas aged EC particles show high CCN activity after experiencing atmospheric processes (Zhang et al., 2008). Pratt et al. (2011) found that number fractions (NFs) of biomass-burning particles internally mixed with ammonium or oxalate increased with the ageing process, which promote their $\mathrm{CCN}$ behavior. Laboratory studies have shown that low-solubility organic particles internally mixed with ammonium sulfate would suppress water uptake of mixed particles and thus might affect $\mathrm{CCN}$ activity (Wise et al., 2003; Svenningsson et al., 2006; Sjogren et al., 2007). An overprediction of CCN concentration by up to $35 \%$ was estimated based on particle internal mixingstate assumptions (Medina et al., 2007; Collins et al., 2013). The influence of mixing state on aerosol $\mathrm{CCN}$ activity varies depending on the proximity to the pollution plume source and/or photochemical ageing activity (Ervens and Volkamer, 2010). More detailed measurements to characterize the mixing state of $\mathrm{CCN}$ particles would improve our understanding of aerosol-cloud interactions.

The combined technique of a counterflow virtual impactor (CVI) and an aerosol mass spectrometer (AMS) or other online or offline single-particle instruments is widely used to characterize the chemical composition and/or mixing state of cloud or fog droplet residue particles. These studies were mainly conducted at sites in North America including Wyoming (Pratt et al., 2010a), Ohio (Hayden et al., 2008), Oklahoma (Berg et al., 2009), Florida (Cziczo et al., 2004; Twohy et al., 2005) and California (Coggon et al., 2014); in Europe including Schmücke (Roth et al., 2016; Schneider et al., 2017), Jungfraujoch (Kamphus et al., 2010), Åresku$\tan$ (Drewnick et al., 2007) and Scandinavia (Targino et al., 2006); in the Arctic (Zelenyuk et al., 2010); in Central America (Cziczo et al., 2013); in western Africa (Matsuki et al., 2010); and in marine areas (Twohy and Anderson, 2008; Twohy et al., 2009; Shingler et al., 2012).

Over the past three decades, China has undergone rapid economic growth accompanied by increased aerosol emissions. Although scientists have worked to increase our understanding of an emissions inventory and the temporal and spatial variation of atmospheric aerosols in China (X. Y. Zhang et al., 2012), few studies have employed direct observation of the chemical composition and mixing state of cloud or fog droplets. W. Li et al. (2011) utilized transmission electron microscopy to obtain the mixing state of individual ambient particles during cloud events at Mount Tai in northern China. This result showed that sulfate-related salts dominated in larger particles. Bi et al. (2016) used a ground- counterflow virtual impactor (GCVI) coupled with a realtime single-particle aerosol mass spectrometer (SPAMS) to explore the chemical composition and mixing state of individual fog residual particles at ground level in an urban area of southern China. They found an abundance of ECcontaining particles in fog residues.

Here, we present a study on the chemical composition and mixing state of individual cloud residue particles at a mountain site in southern China. The same experimental methods of Bi et al. (2016) were used in this study. The size distribution, chemical composition and mixing state of cloud residues during cloud events are discussed. Moreover, the chemical compositions of ambient and nonactivated particles were also compared with the cloud residues. The aim of this study is to assess the potential effects of anthropogenic aerosols from regional transportation on cloud formation and to investigate the dominant particle types in cloud droplets at a mountain site in southern China.

\section{Experimental}

\subsection{Measurement site}

Our measurements were carried out during 15-26 January 2016. The sampling site was located in the Nanling Background Station (112 $53^{\prime} 56^{\prime \prime}$ E, 24 $41^{\prime} 56^{\prime \prime} \mathrm{N}$; 1690 ma.s.l.) at the National Air Pollution Monitoring System in southern China (Fig. S1 in the Supplement). This station is located at $200 \mathrm{~km}$ north of the metropolitan city Guangzhou and $350 \mathrm{~km}$ north of the South China Sea (Fig. S1). This site is also surrounded by a national park forest $\left(273 \mathrm{~km}^{2}\right)$, where there are scarcely any emissions from anthropogenic activities. During the winter monsoon period, air pollution from northern China moves to southern China and crosses the study region (Lee et al., 2005).

\subsection{Instrumentation}

In this study, a GCVI inlet system (GCVI Model 1205, Brechtel Manufacturing Inc.) was used to sample cloud droplets with a diameter greater than $8 \mu \mathrm{m}$. The ambient temperature on average was $6.9^{\circ} \mathrm{C}$ (ranging from -7.2 to $11.4^{\circ} \mathrm{C}$ ) during cloud events. Some mineral dust might trigger heterogeneous ice nucleation at temperature below $-7^{\circ} \mathrm{C}$ (Atkinson et al., 2013). Only 20 cloud residues that accounted for $0.08 \%$ of the total cloud residues were detected when the ambient temperature was below $-7^{\circ} \mathrm{C}$ when observed from 06:00 to 08:00 LT on 23 January. Thus, cloud droplets were dominated by liquid water droplets. The measurements of the droplet size spectra in this region performed during the winter of 1999-2001 showed that sizes of cloud droplets ranged from 4 to $25 \mu \mathrm{m}$, with an average size of $10 \mu \mathrm{m}$ and a corresponding liquid water content of 0.11$0.15 \mathrm{~g} \mathrm{~m}^{-3}$ (Deng et al., 2007). A previous study at another mountain site also showed an average size of $\sim 10 \mu \mathrm{m}$ (Bo- 
rys et al., 2000). Hence, it was assumed that size distribution of cloud droplets was mostly above $8 \mu \mathrm{m}$ in this region. The sampled cloud droplets were passed through an evaporation chamber (air flow temperature at $40^{\circ} \mathrm{C}$ ), where the associated water was removed and the dry residue particles (with the air flow relative humidity $(\mathrm{RH})$ lower than $30 \%$ ) remained. A stream of filtered and heated ambient air (counterflow) was provided by a compressor. The particle transmission efficiency of the cut size $(8 \mu \mathrm{m})$ was $50 \%$. The enrichment factor of the particles collected by the GCVI inlet was estimated to be 5.25 based on theoretical calculation (Shingler et al., 2012). Ambient particles were collected through an ambient inlet with a cut-off aerodynamic diameter $\left(d_{\mathrm{a}}\right)$ of $2.5 \mu \mathrm{m}$ when cloud-free periods were present. Nonactivated (interstitial) particles were sampled through the ambient inlet during the cloud events in this study. The ambient or nonactivated-particle inlet was dried using a silica gel diffusion dryer. During cloud-free periods, a ratio of particle concentration measured behind the CVI (below $\left.1 \mathrm{~cm}^{-3}\right)$ to ambient aerosol concentration $\left(2000 \mathrm{~cm}^{-3}\right)$ was 0.0005 , indicating that instances of particle breakthrough and small particle contamination were absent. The cloud droplet residues, ambient or nonactivated particles were subsequently analyzed by a suite of aerosol measurement devices, including a SPAMS (Hexin Analytical Instrument Co., Ltd., Guangzhou, China), a scanning mobility particle sizer (SMPS; MSP Cooperation) and an Aethalometer (AE-33, Magee Scientific Inc.).

A detailed operational principle of the SPAMS has been described elsewhere (L. Li et al., 2011). Briefly, aerosol particles are drawn into SPAMS through a critical orifice. The particles are focused and aerodynamically sized by two continuous diode Nd:YAG laser beams $(532 \mathrm{~nm})$. The particles are subsequently desorbed and ionized by a pulsed laser $(266 \mathrm{~nm})$ triggered exactly based on the velocity of the specific particle. The positive and negative ions generated are recorded with the corresponding size of individual particles. Polystyrene latex spheres (Nanosphere Size Standards, Duke Scientific Corp., Palo Alto) of 0.2-2.0 $\mu \mathrm{m}$ in diameter were used to calibrate the sizes of the detected particles. The ambient pressure was $830 \mathrm{hPa}(826-842 \mathrm{hPa})$ during the measurements and the calibration. Particles measured by SPAMS mostly fell within the size range of vacuum aerodynamic diameter $\left(d_{\mathrm{va}}\right)$ 0.2-2.0 $\mu \mathrm{m}$ (L. Li et al., 2011).

\subsection{Definition of cloud events}

To reliably identify the presence of cloud events, an upperlimit visibility threshold of $5 \mathrm{~km}$ and a lower-limit RH threshold of $95 \%$ were set in the GCVI software (Bi et al., 2016). Three long-lasting cloud events occurred during the periods of 16:00 LT 15 January to 07:00 LT 17 January (cloud I), 20:00 LT 18 January to 12:00 LT 19 January (cloud II) and 17:00 LT 19 January to 13:00 LT 23 January (cloud III), as marked in Fig. 1. In addition, a cloud event occurred at
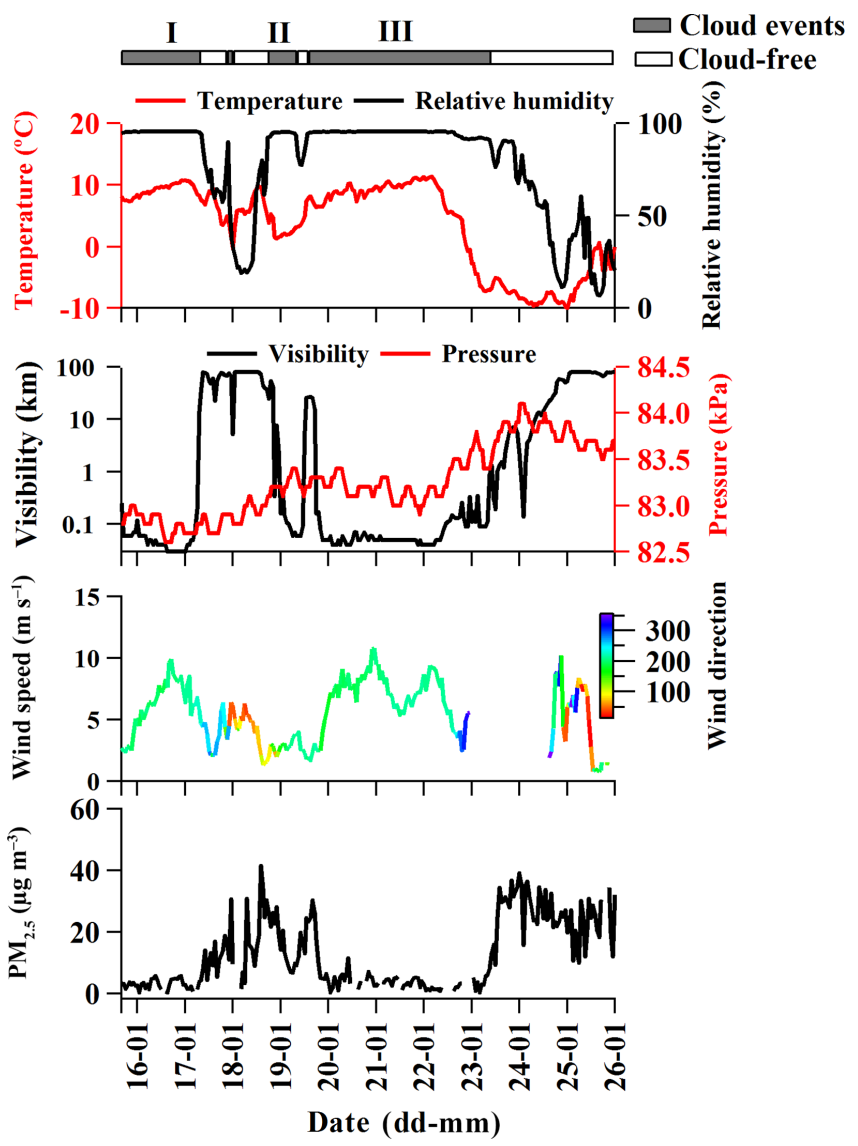

Figure 1. The hourly average variations in meteorological conditions (temperature, relative humidity, visibility, pressure, wind speed and direction) and $\mathrm{PM}_{2.5}$.

14:40-15:00 LT on 17 January, but we did not do an analysis due to the short duration. The measured cloud residual concentration was integrated by the SMPS and was then corrected by the enrichment factor and transmission efficiency of the GCVI. The corrected cloud residual concentrations on average were 436, 568 and $544 \mathrm{~cm}^{-3}$ for cloud I, cloud II and cloud III, respectively (Fig. S2). From 10:00 LT 21 January to 13:00 LT 23 January, cloud residues and nonactivated particles were alternately sampled with an interval of $1 \mathrm{~h}$. During this period, a ratio of number residues to total number particles (sum of cloud residues and nonactivated particle) on average was $0.43 \pm 0.20$. Low levels of $\mathrm{PM}_{2.5}\left(\sim 12.7 \mu \mathrm{g} \mathrm{m}^{-3}\right)$ exclude the influence of hazy days. A rainfall detector of the GCVI system was also used to exclude rain droplet contamination. When cloud events occurred without precipitation, sampling was automatically triggered by the GCVI control software (Bi et al., 2016). 

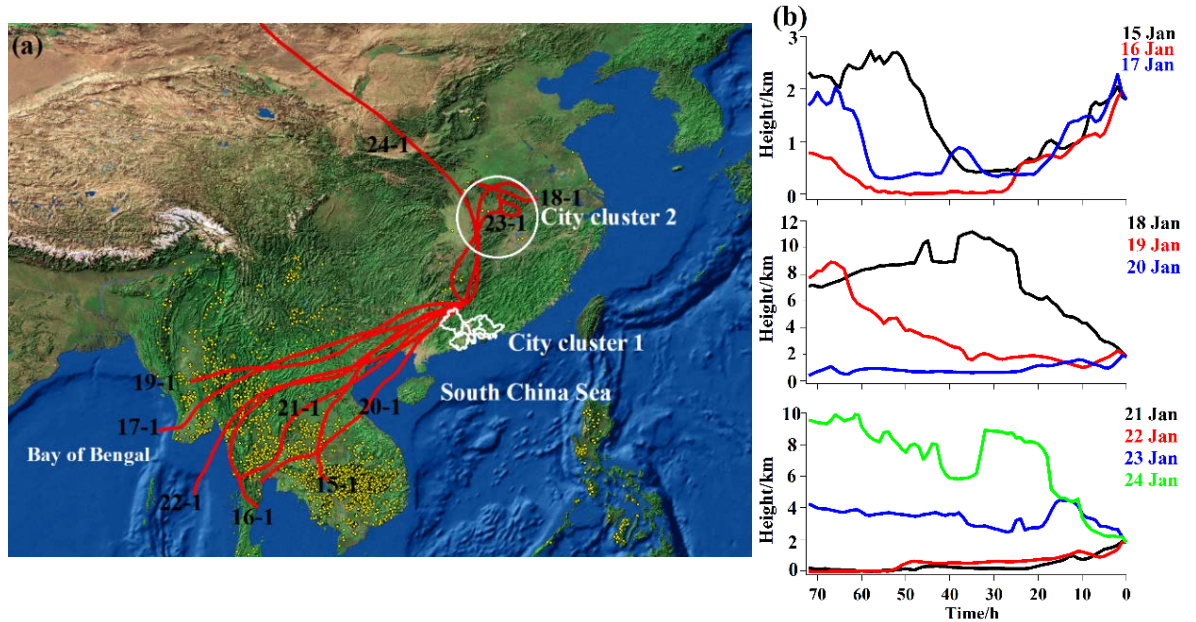

Figure 2. (a) HYSPLIT back trajectories $(72 \mathrm{~h}$ ) for air masses at $1800 \mathrm{~m}$ during the whole sampling period. The white borders and circle refer to the Pearl River Delta (city cluster 1) and Yangtze River mid-reach city clusters (city cluster 2), respectively. The fire data (yellow dots) are available at https://earthdata.nasa.gov/; (b) heights (above sea level) of the air masses as a function of time.

\subsection{Particle classification}

During this study period, a total of 73996 particles including 49322 ambient, 23611 cloud residual and 1063 nonactivated particles with bipolar mass spectra were chemically analyzed in the size range of $d_{\mathrm{va}} 0.2-1.9 \mu \mathrm{m}$. The sampled particles were firstly classified into 101 clusters using an adaptive resonance theory neural network (ART-2a) with a vigilance factor of 0.75 , a learning rate of 0.05 and 20 iterations (Song et al., 1999). Then by manually combining similar clusters, eight major particle types (aged EC, potassiumrich (K-rich), amine, dust, $\mathrm{Fe}, \mathrm{Pb}$, organic carbon $(\mathrm{OC})$ and sodium-rich (Na-rich)) with distinct chemical patterns were obtained, which represented $\sim 99.9 \%$ of the population of the detected particles. The remaining particles were grouped together as "Other". Assuming that the number of individual particles followed Poisson distribution, standard errors for NF of particle type were estimated (Pratt et al., 2010a).

\section{Results and discussion}

\subsection{Back trajectories and meteorological conditions}

Back trajectories in this study were calculated using the Hybrid Single Particle Lagrangian Integrated Trajectory (HYSPLIT) model. A height of the HYSPLIT model in the study region (a spatial resolution of $0.5^{\circ} \times 0.5^{\circ}$ ) is averaged 500 ma.s.l., lower than the height of the observed site $(1690 \mathrm{~m}$ a.s.l.). Thus, a height of $1800 \mathrm{~m}$ a.s.l. (approximately $100 \mathrm{~m}$ above the observed site) was chosen as an endpoint in the model. The station was mainly affected by southwesterly or northerly air masses in this study (Fig. 2). In addition, the beginning altitude of the southwesterly air masses traversed at lower heights relative to the northerly air masses (Fig. 2). The southwesterly air masses, accompanied by warm moist airflows, occurred during $15-17$ and 20-21 January, which promoted high RH condition (Fig. 1). Conversely, the northerly air masses, associated with cool dry airstreams, occurred during 18 and 23-24 January and led to a decrease in temperature and RH. Note that, on 1819 and 22-23 January, the air mass encountered initial mixing of northerly cloud-free air and southwesterly cloudy air. Entrainment of nuclei particles originated from northern air masses might be activated to cloud droplets (Sect. 3.4).

Meteorological conditions were unstable, with high southwesterly flow $\left(\sim 6.5 \mathrm{~m} \mathrm{~s}^{-1}\right)$ during $15-17$ and $20-22$ January (Fig. 1). The level of $\mathrm{PM}_{2.5}$ remained a low value of approximately $3 \mu \mathrm{g} \mathrm{m}^{-3}$ for this time period. A high level of $\mathrm{PM}_{2.5}$ $\left(\sim 20 \mu \mathrm{g} \mathrm{m}^{-3}\right)$ was observed during 18 January when the northerly flow dominated. Similarly, the average $\mathrm{PM}_{2.5}$ value reached $24 \mu \mathrm{g} \mathrm{m}^{-3}$ during 24 January. Although the local northerly and southwesterly flows occurred alternately, the particles were still originated from the northerly air mass for this period (Fig. 2). During 23-24 January, a sharp decrease in temperature (Fig. 1) was observed due to a cold wave associated with a violent northerly flow. The wind speed during the cold wave exceeded the upper-limit speed $\left(\sim 12 \mathrm{~m} \mathrm{~s}^{-1}\right)$ of a wind speed sensor.

\subsection{The chemical characterization of cloud droplet residues}

Figure 3 shows the average positive and negative mass spectra of the main six particle types. The aged $\mathrm{EC}$ particles were characterized by EC cluster ions (e.g., $m / z \quad 12 \mathrm{C}^{ \pm}, 36 \mathrm{C}_{3}^{ \pm}$, $\left.48 \mathrm{C}_{4}^{ \pm}, 60 \mathrm{C}_{5}^{ \pm}, \ldots\right)$ and a strong $\mathrm{K}^{+}$ion signal $\left(\mathrm{m} / \mathrm{z} 39 \mathrm{~K}^{+}\right)$ as well as a sulfate ion signal $\left(m / z-97 \mathrm{HSO}_{4}^{-}\right)$, and some minor organic markers $\left(m / z 27 \mathrm{C}_{2} \mathrm{H}_{3}^{+}, 43 \mathrm{C}_{2} \mathrm{H}_{3} \mathrm{O}^{+}\right.$; Moffet 

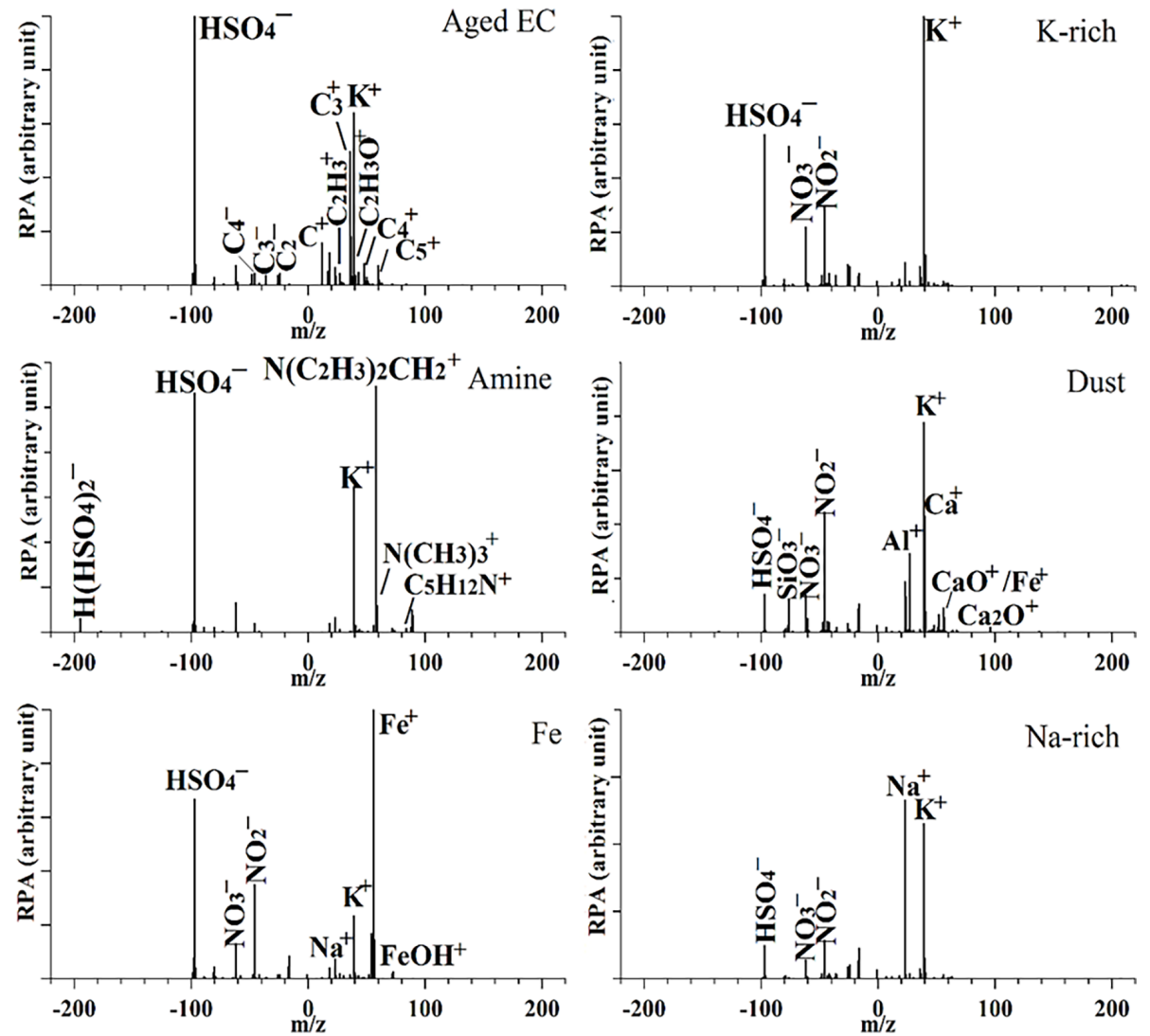

Figure 3. Averaged positive and negative mass spectra for the main six particle types (aged EC, K-rich, amine, dust, Fe and Na-rich) of the sampled particles. RPA on the vertical axis refers to relative peak area. On the horizontal axis, $m / z$ represents mass-to-charge ratio.

and Prather, 2009). EC particles mainly originated from combustion processes (Bond et al., 2013). The strong $\mathrm{K}^{+}$ion signal in the aged EC particles implies that they partially originated from biomass-burning sources (Bi et al., 2011). The aged EC particle type was the largest fraction (49.3\%) of the total cloud residues (Fig. S3). In addition, the NF of the aged EC residues significantly decreased from $54.1 \%$ in the size range of $0.2-1.0 \mu \mathrm{m}$ to $19.2 \%$ in the size range of $1.1-1.9 \mu \mathrm{m}$ (Fig. 4). Note that the chemical composition of cloud residues is dependent on the particle size (Roth et al., 2016), and the number reported for each particle type might suffer from the bias related to size-dependent transmission efficiency (Qin et al., 2006). The relative fraction of cloud residues in the $0.1 \mu \mathrm{m}$ size interval is presented to minimize the influence of size-dependent transmission efficiency of single-particle mass spectrometry (Roth et al., 2016).

The K-rich particles exhibited the highest peak at $\mathrm{m} / \mathrm{z}$ $39 \mathrm{~K}^{+}$, mainly combined with sulfate and nitrate $(\mathrm{m} / \mathrm{z}$ $-46 \mathrm{NO}_{2}^{-},-62 \mathrm{NO}_{3}^{-}$) and presumably derived from biomass and/or biofuel burning sources (Moffet et al., 2008; Pratt et al., 2011; Zhang et al., 2013). An aged time of 81$88 \mathrm{~min}$ biomass-burning particles were found to show an increase in the mass fractions of ammonium, sulfate and nitrate (Pratt et al., 2011). In this study, the K-rich parti-

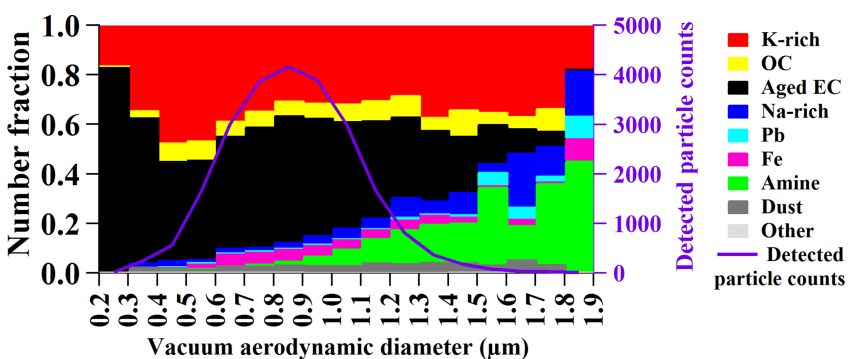

Figure 4. Number fractions for size distribution of the cloud residual types in $100 \mathrm{~nm}$ size intervals.

cles would be expected to experience aged process due to strong sulfate and nitrate signals (Hudson et al., 2004; Pratt et al., 2011). Aged biomass-burning particles can participate in cloud droplet formation and show an effective $\mathrm{CCN}$ activity (Pratt et al., 2010a). The K-rich particle type, the second largest contributor, accounted for $33.9 \%$ of the total cloud residues (Fig. S3).

The abundant aged soot, EC and biomass-burning particles were often detected in cloud residues (Pratt et al., 2010a; Roth et al., 2016). The contribution of local anthropogenic origins to aged soot and/or biomass-burning parti- 
cles in cloud or fog residues has been reported in Schmücke (Roth et al., 2016) and Guangzhou city (Bi et al., 2016). At the North Slope of Alaska, the measurement of biomassburning particles in cloud residues mainly resulted from the local vicinity, or sources as far away as Siberia and Asia (Zelenyuk et al., 2010; Hiranuma et al., 2013). Similarly, the majority of aged EC and K-rich cloud residues observed here are expected to originate from long-range transportation due to insignificant sources of local anthropogenic emissions and the fire dots (Fig. 2). At the Jungfraujoch station (3580 ma.s.1.) in Europe, the K-rich (biomass-burning) particles only contributed $3 \%$ of the cloud droplets, and the aged EC residuals were insignificant ( $<1 \%$; Kamphus et al., 2010). The Jungfraujoch station is predominantly within the free tropospheric condition, such that the biomass-burning contribution can be expected to be lower than at other sites.

The amine particles were characterized by related amine ion signals at $m / z \quad 58 \mathrm{C}_{2} \mathrm{H}_{5} \mathrm{NHCH}_{2}^{+}$(diethylamine, DEA), $59 \mathrm{~N}\left(\mathrm{CH}_{3}\right)_{3}^{+}$(trimethylamine, TMA) and $86 \mathrm{C}_{5} \mathrm{H}_{12} \mathrm{~N}^{+}$(triethylamine, TEA; Angelino et al., 2001; Moffet et al., 2008). This particle type also contained sulfuric acid ion signals at $m / z-195 \mathrm{H}\left(\mathrm{HSO}_{4}\right)_{2}^{-}$, indicative of acidic particles (Rehbein et al., 2011). The amine particles represented $3.8 \%$ of the total cloud residues (Fig. S3). Higher NF of the amine residues was detected in the size range from 0.7 to $1.9 \mu \mathrm{m}$ relative to the size range from 0.2 to $0.6 \mu \mathrm{m}$ (16.7 vs. $0.4 \%$ ), as shown in Fig. 4. Aqueous reactions improving the participation of amine have been observed in Guangzhou (G. Zhang et al., 2012) and southern Ontario (Rehbein et al., 2011). A recent study also showed a clear enhancement of amine-containing particles in cloud residues compared to the ambient particles ( 9 vs. $2 \%$; Roth et al., 2016). It indicates a preferential formation of amine within the cloud, which is in contrast to the observations of $\mathrm{Bi}$ et al. (2016). It might suggest that enhancement of particle amine is not only dependent on high RH or fog or cloud processes, but is also sensitive to other parameters, such as the presence of gas-phase amine sources (Rehbein et al., 2011).

The dust particles presented significant ions at $\mathrm{m} / \mathrm{z}$ $40 \mathrm{Ca}^{+}, 56 \mathrm{CaO}^{+} / \mathrm{Fe}^{+}, 96 \mathrm{Ca}_{2} \mathrm{O}^{+}$and $-76 \mathrm{SiO}_{3}^{-}$and sulfate as well as nitrate markers. Previous studies showed that dust particles that are internally mixed with sulfate and nitrate are expected to act as CCN (Twohy and Anderson, 2008; Twohy et al., 2009), despite sulfate and nitrate partially forming from in-cloud production. This type contributed $2.9 \%$ of the total cloud residues (Fig. S3). A slight increase in NF of the dust residues was observed in the size range above $0.5 \mu \mathrm{m}$ relative to that below $0.5 \mu \mathrm{m}(3.0$ vs. $1.0 \%)$. At Mount Tai in northern China, a high concentration of $\mathrm{Ca}^{2+}$ in cloud or fog water was mainly attributed to a sandstorm event during the spring season (Wang et al., 2011). At Mount Heng in southern China, the abundant crust-related elements (e.g., $\mathrm{Al})$ observed in cloud water is due to Asian dust storms that occurred in March-May (Li et al., 2017). Based on the back- ward trajectory, the site was unlikely affected by sandstorm source in northwestern China during the cloud events. Local dust emissions from anthropogenically disturbing soils or removing vegetation cover can be excluded as a result of forest protection. Additionally, dust residues may have occupied larger CCN (Tang et al., 2016), which cannot be detected by the SPAMS. Hence, a low fraction $(2.9 \%)$ of dust cloud residue might be due to the limitation of the SPAMS.

The Fe particles, internally mixed with sulfate and nitrate and with typical ions at $m / z 56 \mathrm{Fe}^{+}$, made up $4.1 \%$ of the total cloud residues. Approximately $16 \%$ of the $\mathrm{Fe}$ cloud residues contained $\mathrm{Ca}^{+}$peak $(\mathrm{m} / \mathrm{z} 40)$. Predominant Fe ion peaks possibly indicate the contribution from anthropogenic sources (Zhang et al., 2014), especially the northern air masses across iron and steel industrial activities in Yangtze River mid-reach city clusters (Fig. 2). The contribution of anthropogenic and natural Fe-containing particle sources (Moteki et al., 2017) to observed Fe-containing residues is expected. The presence of $\mathrm{Fe}$ in the cloud droplets plays an important role in aqueous-phase $\mathrm{SO}_{2}$ catalytic oxidation in cloud processing (Harris et al., 2013), thus accelerating the sulfate content of Fe-containing particles in cloud processing.

The Na-rich particles were mainly composed of ion peaks at $m / z 23 \mathrm{Na}^{+}$and $39 \mathrm{~K}^{+}$in the positive mass spectra, and nitrate and sulfate species in the negative mass spectra made up $3.0 \%$ of the total cloud residues. Na-rich particles are formed from varied sources including industrial emissions, sea salt or dry lake beds (Moffet et al., 2008). The NF of Na-rich cloud residues did not increase from continental (northerly) air mass on 19 January to maritime (southwesterly) air mass on 21 January (3.3 vs. $2.4 \%$ ). However, the related sea salt ion peak area $\left(m / z, 81 / 83 \mathrm{Na}_{2}{ }^{35} \mathrm{Cl}^{+} / \mathrm{Na}_{2}{ }^{37} \mathrm{Cl}^{+}\right)$were enhanced for $\mathrm{Na}$-rich particles originating from maritime air mass relative to continental air mass (3.8 \pm 2.4 times). The continental air masses crossed industrial areas where the Yangtze River mid-reach city cluster is located (Fig. 2). Industrial emissions were a possible contributor to Na-rich particles under the influence of continental air masses (Wang et al., 2016). This might suggest that the Na-rich particles originated from both industrial emissions and sea salts.

The OC, $\mathrm{Pb}$ and Other particle types contributed $0.1-2.3 \%$ to the total cloud residues (Fig. S3). Their average mass spectra can be found in Fig. S4. The OC particles presented dominant intense OC signals (e.g., $m / z 27 \mathrm{C}_{2} \mathrm{H}_{3}^{+}, 37 \mathrm{C}_{3} \mathrm{H}^{+}$, $43 \mathrm{C}_{2} \mathrm{H}_{3} \mathrm{O}^{+}$and $51 \mathrm{C}_{4} \mathrm{H}_{3}^{+}$) and abundant sulfate. Presence of $\mathrm{K}^{+}$signal was found in the OC particles, suggesting possible biomass-burning sources (Bi et al., 2011). OC particles might exist in smaller cloud residues (Sellegri et al., 2003a), which cannot be detected by the SPAMS. The Pb particles had typical ions at $m / z 208 \mathrm{~Pb}^{+}$and were internally mixed with $\mathrm{K}^{+}$ and $\mathrm{Cl}^{-}$. Previous studies have found that $\mathrm{K}$ and $\mathrm{Cl}$ internally mixed with $\mathrm{Pb}$ particles have a possible origination of waste incineration (Zhang et al., 2009) or iron and steel product 
manufacturing facilities (Tsai et al., 2007). Only three particles were found containing calcium, organic carbon, organic nitrogen and phosphate ion signals, implying a possible existence of biological particles (Pratt et al., 2009a). Such particles were classified as the Other type due to low number.

Previous measurements have found that dust, playa salts, sea salt or metal particles were often enriched in larger cloud droplets $(\sim 20 \mu \mathrm{m}$; Bator and Collett, 1997; Moore et al., 2004; Pratt et al., 2010b). Organic carbon tended to be enriched in small cloud or fog droplets, extending to $4 \mu \mathrm{m}$ (Herckes et al., 2013). The size of cloud droplets were above $8 \mu \mathrm{m}$ in the present study. Additionally, the particle transmission efficiency increased with increasing cloud droplet size (Shingler et al., 2012). Thus, it partially leads to relatively larger fractions of the observed dust, Na-rich and metal cloud residues, and the smaller fraction of the $\mathrm{OC}$ cloud residues in this study.

\subsection{Mixing state of secondary species in cloud residues}

The high NFs of sulfate-containing particles were found in the K-rich (91\%), OC (100\%), aged EC (98\%), Pb (74\%), $\mathrm{Fe}(93 \%)$ and amine $(99 \%)$ cloud residues, as shown in Fig. 5. Lower NFs of sulfate-containing particles were observed in the Na-rich $(41 \%)$ and dust $(42 \%)$ cloud residues. In contrast, nitrate-containing particles contributed 89 and $88 \%$ to the Na-rich and dust cloud residues, respectively. The acid displacement reaction of sea salt chloride (Na-rich particles) by $\mathrm{HNO}_{3}$ might lead to a depletion of chloride and enhancement of nitrate (Laskin et al., 2012). Similarly, the heterogeneous chemistry of $\mathrm{HNO}_{3}$ in the dust particles also contributes the preferential enrichment of nitrate (Tang et al., 2016). Moreover, after activation, uptake of gas-phase $\mathrm{HNO}_{3}$ would increase nitrate level in the cloud residues (Schneider et al., 2017). The nitrate in the cloud residues was thought to be in the form of ammonium nitrate by estimating the ratio of $m / z, 30$ to $m / z 46$ in AMS data (Drewnick et al., 2007; Hayden et al., 2008). Relative to nitrate, low portions of ammonium $\left(\mathrm{m} / z, 18 \mathrm{NH}_{4}^{+}\right)$in the Na-rich $(23 \%)$ and dust $(15 \%)$ cloud residues suggest that in this region, ammonium nitrate was not a predominant form of nitrate in the two cloud residual types. The Na-rich and dust types were mainly composed of alkaline ion peaks $\left(\mathrm{m} / z, 23 \mathrm{Na}^{+}, 39 \mathrm{~K}^{+}\right.$and $\left.40 \mathrm{Ca}^{+}\right)$ in mass spectra (Fig. 3), accompanied by a larger fraction $(88-89 \%)$ of nitrate. Thus, our data suggest that nitrate might exist in the form of $\mathrm{Ca}\left(\mathrm{NO}_{3}\right)_{2}, \mathrm{NaNO}_{3}$ or $\mathrm{KNO}_{3}$ in the dust and Na-rich cloud residues. It should be noted that the evaporation chamber of the GCVI may lead to a reduction of ammonium nitrate in the cloud residues (Hayden et al., 2008). The nitrate-containing particles accounted for only $46 \%$ of the aged EC cloud residues, which is significantly less than the sulfate-containing particles. Previous field studies have found that aged EC (soot) fog/cloud residues are mainly internally mixed with sulfate (Pratt et al., 2010a; Harris et al., 2014; Bi et al., 2016). Aged EC particles mixed with sulfate

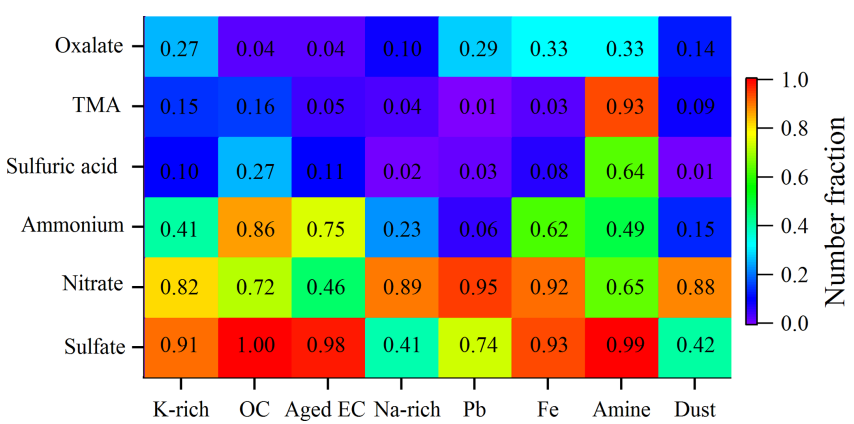

Figure 5. Number fractions of secondary markers associated with the total cloud residues types: sulfate $\left(m / z,-97 \mathrm{HSO}_{4}^{-}\right)$, nitrate $\left(m / z,-46 \mathrm{NO}_{2}^{-}\right.$or $\left.-62 \mathrm{NO}_{3}^{-}\right)$, ammonium $\left(m / z, 18 \mathrm{NH}_{4}^{+}\right)$, sulfuric acid $\left(m / z,-195 \mathrm{H}\left(\mathrm{HSO}_{4}\right)_{2}^{-}\right)$, TMA $\left(m / z, 59 \mathrm{~N}\left(\mathrm{CH}_{3}\right)_{3}^{+}\right)$and oxalate $\left(m / z,-89 \mathrm{HC}_{2} \mathrm{O}_{4}^{-}\right)$.

are good CCN (Bi et al., 2016; Roth et al., 2016). Laboratory measurements have also demonstrated that EC particles internally mixed with sulfate showed a high hygroscopic behavior and thus affect CCN ability (McMeeking et al., 2011). High portions (75-86\%) of ammonium-containing particles were observed for the OC and aged EC cloud residues, suggesting that ammonium will mostly be in the form of ammonium sulfate or ammonium nitrate for the two cloud residual types. This result also implies that ammonium-containing particles are preferentially activated or enhanced uptake of gaseous $\mathrm{NH}_{3}$ to neutralize acidic cloud droplets for the OC and EC types.

Water soluble organics (e.g., amine and oxalate) have previously been measured in cloud water or residues (Sellegri et al., 2003b; Sorooshian et al., 2007a; Pratt et al., 2010a). The presence of TMA (93\%) in the amine cloud residues is expected to promote water uptake activity (Sorooshian et al., 2007b). A total of 3410 oxalate-containing particles $(\mathrm{m} / \mathrm{z}$, $-89 \mathrm{HC}_{2} \mathrm{O}_{4}^{-}$) represented $14.4 \%$ of the total cloud residues, which was mainly associated with the K-rich cloud residues $(\sim 70 \%)$. Oxalate-containing particles $(\sim 30 \%)$ in the metal $(\mathrm{Pb}, \mathrm{Fe})$ cloud residues might be in the form of metal oxalate complexes from reactions of in-cloud formation oxalate with metals (Furukawa and Takahashi, 2011). Oxalate can readily partition into the particle phase to form amine salts (Pratt et al., 2009b). It may facilitate the entrainment of oxalate $(33 \%)$ in the amine residues. A low fraction $(4 \%)$ of oxalate-containing particles in the $\mathrm{OC}$ type is a result of restrictive classification. Classification of the OC particles is mainly based on intense organic carbon ion signals (e.g., $m / z$ $27 \mathrm{C}_{2} \mathrm{H}_{3}^{+}, 37 \mathrm{C}_{3} \mathrm{H}^{+}, 43 \mathrm{C}_{2} \mathrm{H}_{3} \mathrm{O}^{+}$and $51 \mathrm{C}_{4} \mathrm{H}_{3}^{+}$).The majority of oxalate-containing particles were internally mixed with the K-rich type. Therefore, oxalate was classified as the Krich type and was probably contributed from biomass burning. The K-rich particles could contain an abundance of organics (Pratt et al., 2011); however, the signals of organics 


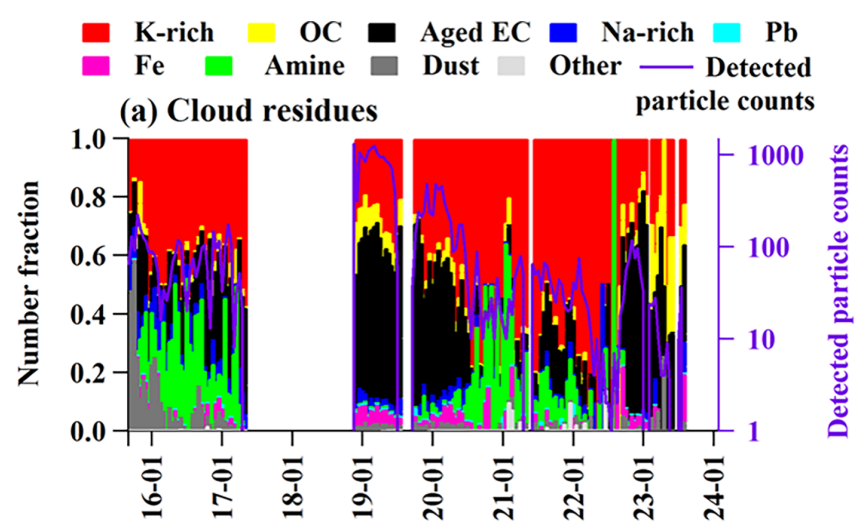

(b) Ambient particles

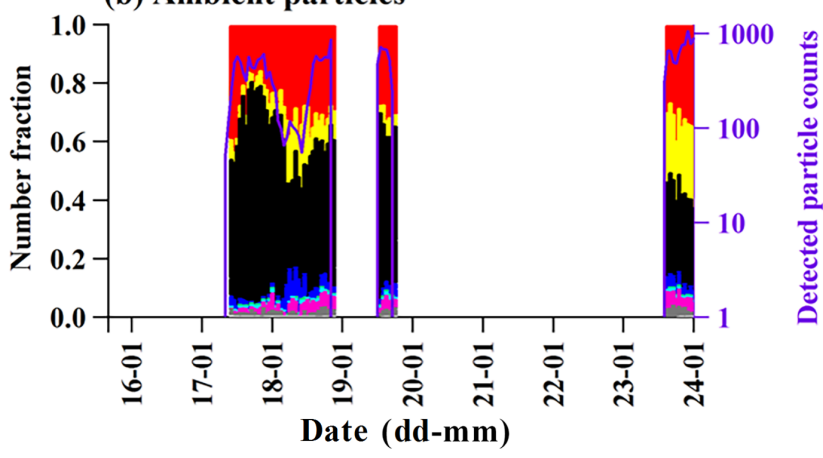

Figure 6. The hourly average variations in the cloud residual and ambient particles during the whole sampling period.

were covered by the potassium due to its high sensitivity to the laser.

\subsection{Comparison of cloud residues in different air mass sources}

Figure 6 displays the hourly detected particle counts and $\mathrm{NF}$ values of the nine types of cloud residues and ambient particles. The NF of the aged EC type showed a very abrupt increase from cloud residues to ambient particles on 17 January. The ambient RH showed an abrupt decrease from nearly $100 \%$ at 10:00 LT to $85 \%$ at 11:00 LT on 17 January (Fig. 1). The ambient temperature also decreased from $10^{\circ} \mathrm{C}$ at $11: 00 \mathrm{LT}$ to $4^{\circ} \mathrm{C}$ at 18:00 LT on 17 January (Fig. 1). These changes imply that the air mass shifted from southwesterly cloudy air to northerly cloud-free air around noon on 17 January (Fig. 2). The entrained particles that originated from northern air mass might have insufficient supersaturation to be activated as cloud droplets. It resulted in the remarkable increase of the aged EC particles in ambient particles on 17 January (Fig. 6).

The ambient RH increased from $60 \%$ at 19:00 LT to nearly $100 \%$ at $21: 00$ LT on 18 January (Fig. 1). The ambient temperature also increased from $1.3^{\circ} \mathrm{C}$ at 22:00 LT on 18 January to $3.2^{\circ} \mathrm{C}$ at $06: 00 \mathrm{LT}$ on 19 January (Fig. 1). These changes imply that the air mass changed from northerly cloud-free air to southwesterly cloudy air at night on 18 January (Fig. 2). During 18-19 January, the cloud residues and ambient particles showed similar chemical characteristics and were dominated by aged EC particles (Fig. 6). A lack of significant variation in the particle types for this period suggests that nuclei particles originated from northerly cloud-free air could be activated to become cloud droplets. When a cloud-free event occurred at 11:00-17:00 LT on 19 January, ambient particles retained a high level of $\mathrm{PM}_{2.5}\left(\sim 22.7 \mu \mathrm{g} \mathrm{m}^{-3}\right)$. The southwesterly wind flow on 19-20 January was too weak $\left(\sim 2.75 \mathrm{~m} \mathrm{~s}^{-1}\right)$ to dilute particles that originated from the northerly air masses (Fig. 1). Additionally, a high RH (90\%) air mass at $1500 \mathrm{~m}$ a.s.l. gradually moved to northern China from 19 to 20 January (Fig. S5). These changes might have led to similar residual particle types observed from 19 to 20 January, although the site encountered southwesterly cloudy air on 19-20 January (Fig. 2).

As mentioned above, the NF of the cloud residue types significantly changed as the air mass origin varied from northerly to southwesterly. To further investigate the influence of air mass history, we chose to analyze cloud residues that had arrived from a northerly air mass on 18-19 January compared to cloud residues that originated from a southwesterly air mass during the periods of 16-17 and 21-22 January. The detected number of cloud residues for both the northerly and southwesterly air masses are given in Table S1. The southwesterly air masses accompanied by high RH $(90 \%$; Fig. S5) may have triggered particles activated to $\mathrm{CCN}$ prior to their arrival at the sampling site.

The K-rich type was found to contribute $23.9 \%$ to the cloud residues in the northerly air mass, which was significantly lower than its contribution to the southwesterly air mass $(51.5 \%)$, as shown in Fig. 7. A similarity in averaged mass spectrum of the K-rich residues was found for the southwesterly and northerly air masses (Fig. S6). The considerable increase of K-rich cloud residues suggests a major influence of regional biomass-burning activities. Biomassburning emissions from Southeast Asia, including Myanmar, Vietnam, Laos and Thailand, where abundant fire dots are observed (Fig. 2), could have been transported to the sampling site under a southwesterly air mass (Duncan et al., 2003). In contrast, the aged EC type represented only $23.7 \%$ of the cloud residues under the influence of the southwesterly air mass, which was significantly lower than observations for the northerly air mass (59.9\%), as shown in Fig. 7. This result suggests that the northern air mass has a greater influence on the presence of aged EC cloud residues.

An obvious increase in NF of the amine type was observed in the southwesterly air mass $(15.1 \%)$ compared to the northerly air mass $(0.2 \%)$, as shown in Fig. 7 . These data imply that the sources or formation mechanisms of amine in cloud residues varied in different air masses. The southwesterly air masses arrived from as far as the Bay of Bengal and then traveled through the Southeast Asia region before reach- 
(a) Residues (northerly)

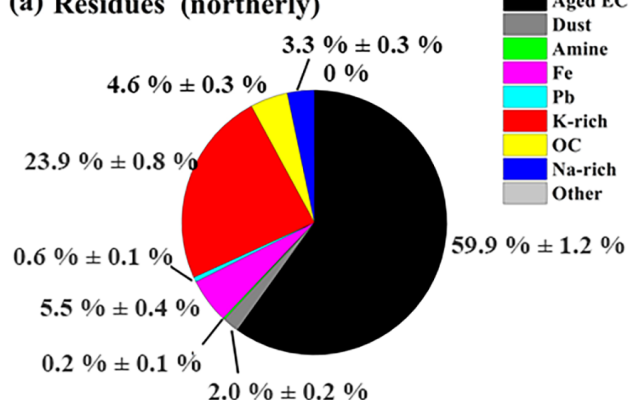

(c) Residues (southwesterly)

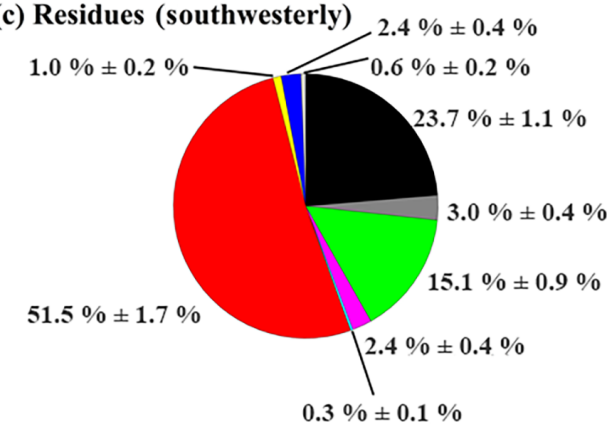

(d) Residues

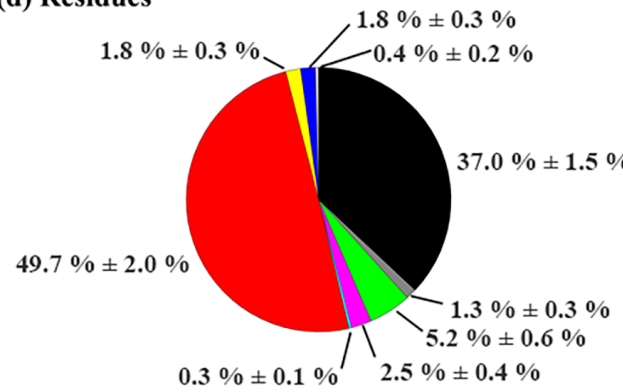

(b) Ambient (northerly)

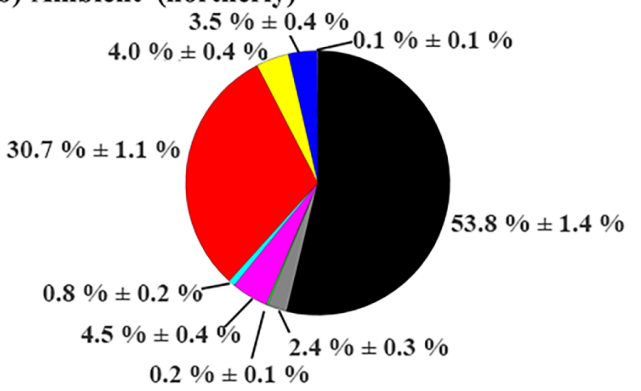

(e) Nonactivated

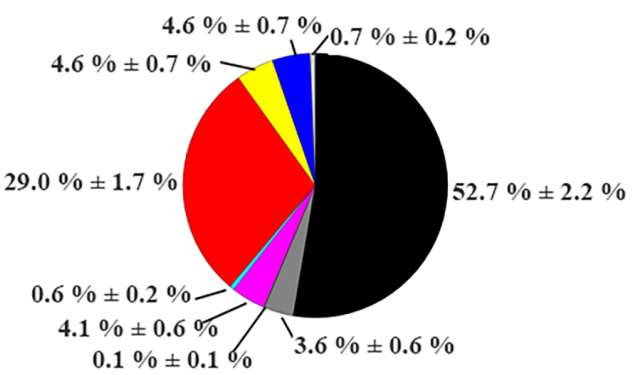

Figure 7. Number fractions of the cloud residues, ambient particles and nonactivated particles; (a) cloud residues during northerly air mass; (b) ambient particle during northerly air mass; (c) cloud residues during southwesterly air mass; (d) cloud residues; and (e) nonactivated particles were alternately sampled with an interval of $1 \mathrm{~h}$ during the cloud III event. Uncertainties were calculated assuming Poisson statistics for analyzed particles.

ing southern China (Fig. 2). The potential gas amine emissions from ocean (Facchini et al., 2008) and livestock areas (90 million animals; data are available at the website http: //faostat3.fao.org) in the Southeast Asia region might promote the enrichment of amine particles. Furthermore, after activation, the partitioning of the gas amine on cloud droplets may further contribute to the enhanced amine cloud residues (Rehbein et al., 2011), especially for air masses delivered via routes with high $\mathrm{RH}$, as mentioned above (Fig. S5). In contrast, northerly air mass accompanied with dry airstreams may unfavorably induce the partitioning of gas amines into the particle phase (Rehbein et al., 2011).

\subsection{Comparison of cloud residues with ambient and nonactivated particles}

A direct comparison between cloud residues and ambient particles was limited because of their differences in air mass origins. During the sampling period, the cloud events occurred once the southwesterly air masses were dominant. Hence a comparison between cloud residues and ambient particles cannot be addressed under the influence of southwesterly air masses. Here, we chose $5 \mathrm{~h}$ before and after the beginning of the cloud II period in order to compare cloud residues and ambient particles with similar northerly air mass origins, as discussed in Sect. 3.4.

The cloud residues and nonactivated particles were alternately sampled with an interval of $1 \mathrm{~h}$ from 21 January to 

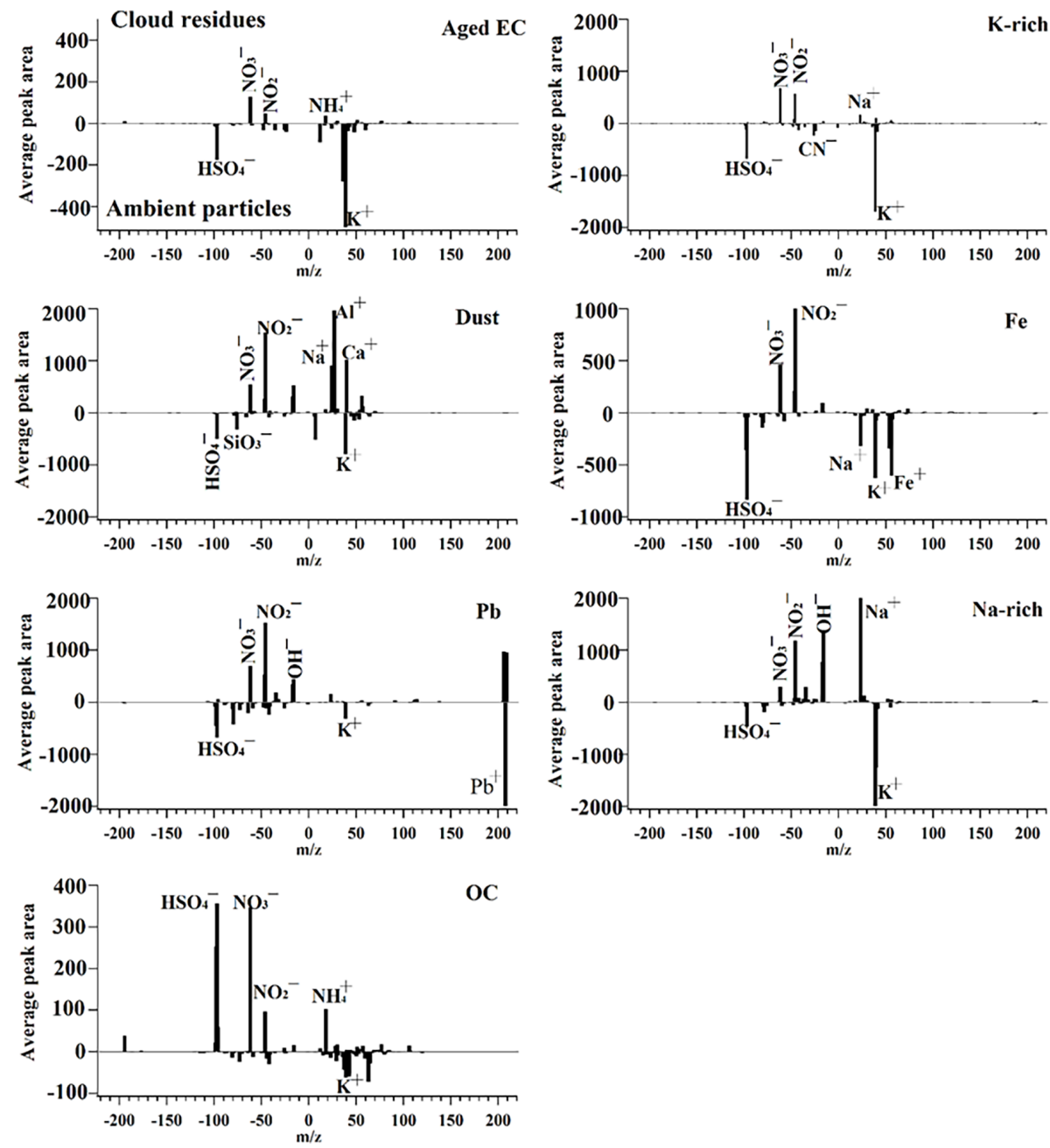

Figure 8. Mass spectral subtraction plot of the average mass spectrum corresponding to cloud residues minus ambient particles. Positive area peaks correspond to higher abundance in cloud residues, whereas negative area peaks show higher intensity in ambient particles.

23 January. The ambient temperature decreased from $6{ }^{\circ} \mathrm{C}$ at 11:00 LT to $0^{\circ} \mathrm{C}$ at 23:00 LT on 22 January (Fig. 1). The ambient-particle level (sum of residual and nonactivated particles) showed a clear increase from 156 to $1460 \mathrm{~cm}^{-3}$ during this period (Fig. S2). Thus, the data suggest that the initial mixing of northerly cloud-free air and southwesterly cloudy air occurred at around noon on 22 January. A reduction of supersaturation due to entrainment of the dry northern air mass might have insufficient moisture to activate small particles, leading to nonactivated particles above $0.2 \mu \mathrm{m}$ (Fig. S7; Mertes et al., 2005; Kleinman et al., 2012; Hammer et al., 2014), which can be detected by the SPAMS.

The contribution of K-rich particles in cloud residues $(23.9 \%)$ slightly decreased relative to ambient particles $(30.7 \%)$, as shown in Fig. 7. Previous studies have found that there were no significant changes in NF of biomassburning particles for cloud residues relative to ambient particles (Pratt et al., 2010a; Roth et al., 2016). The biomassburning particles internally mixed with soluble species (e.g., sulfate, nitrate and oxalate) enhanced their ability to act as CCN, as discussed in Sect. 3.3. Kamphus et al. (2010) reported that biomass-burning particles account for only $3 \%$ of cloud residues compared with $43 \%$ of ambient particles, and they suspected that biomass-burning particles might exist in the form of tar balls (hydrophobic materials). A slight increase in NF of the aged EC cloud residues $(59.9 \%)$ was observed relative to ambient particles $(53.8 \%)$, as shown in Fig. 7. In general, freshly emitted EC particles are less hydrophilic and are not active as CCN (Bond et al., 2013). The aged EC particles show a high degree of internal mixing with secondary inorganic compounds in this study (Fig. 5), improving their ability to act as $\mathrm{CCN}$. The remaining particle types showed no clear differences in NF between cloud residues and ambient particles.

When comparing the cloud residues with nonactivated particles, a significant change in NF was found for the aged EC and K-rich type. A higher NF of K-rich particles and a lower $\mathrm{NF}$ of EC particles were found for the cloud residues rel- 

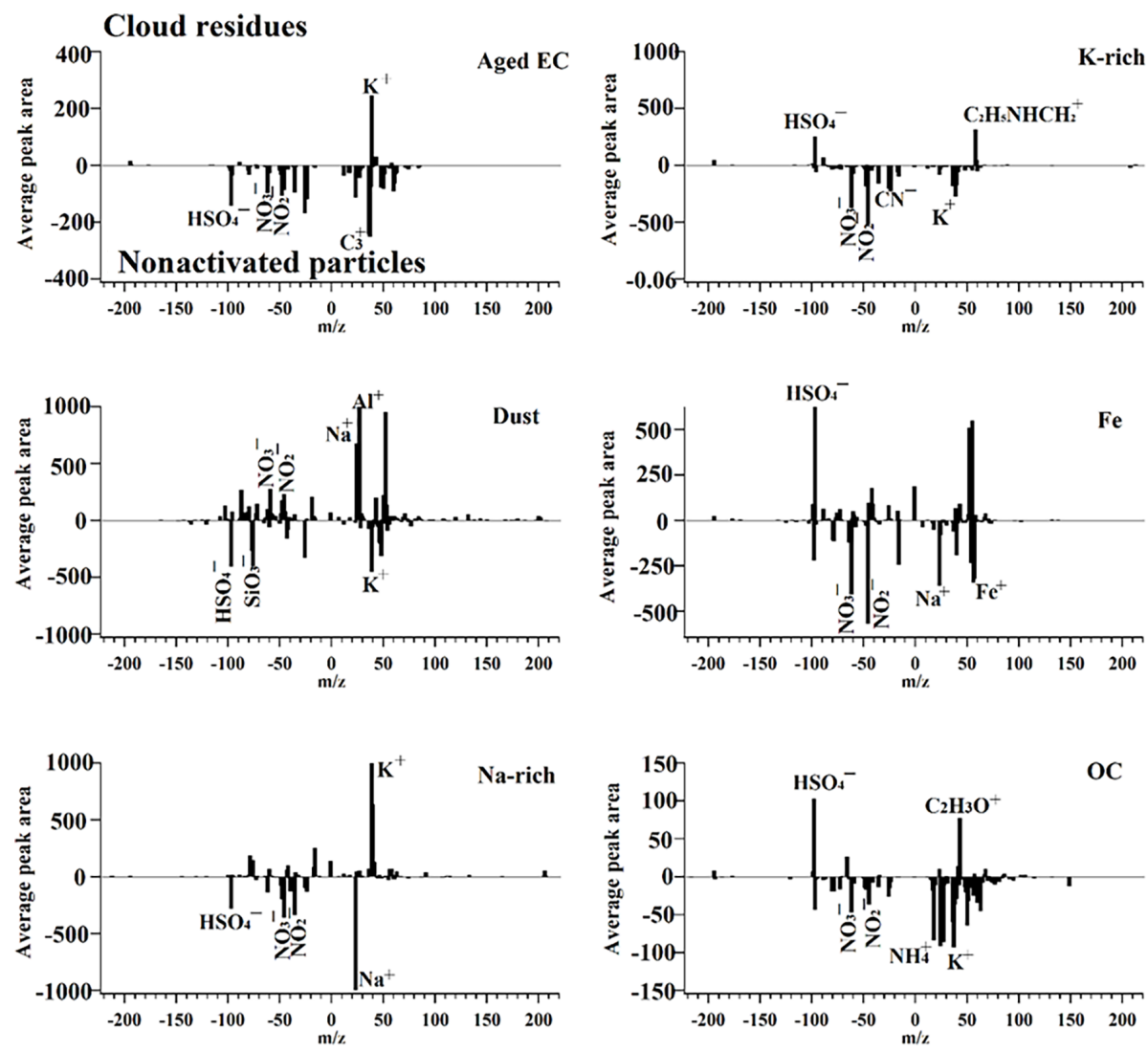

Figure 9. Mass spectral subtraction plot of the average mass spectrum corresponding to cloud residues minus nonactivated particles. Positive area peaks correspond to higher abundance in cloud residues, whereas negative area peaks show higher intensity in nonactivated particles.

ative to the nonactivated particles (Fig. 7). Entrainment of northerly cloud-free air might lower supersaturation during this period. Aged EC particles may require very high supersaturation to grow into cloud droplets and, thus, only form hydrated nonactivated aerosol (Hallberg et al., 1994).

Figures 8 and 9 show the differences in average mass spectra for cloud residues vs. ambient particles as well as cloud residues vs. nonactivated particles, respectively. Nitrate intensity (average ion peak area) enhanced in the cloud residues when compared to ambient particles. In addition, nitrate-containing particles accounted for $70 \%$ of the cloud residues compared to $38 \%$ of the ambient particles. Drewnick et al. (2007) suggested that rather than sulfate, high nitrate content in pre-existing particles preferentially acted as cloud droplets. Compared with nitrate-containing ambient particles, the larger sizes of nitrate-containing residues (Fig. S8) possibly reflect the uptake of gaseous $\mathrm{HNO}_{3}$ during cloud processes (Hayden et al., 2008; Roth et al., 2016). A recent study also confirmed that the update of gaseous $\mathrm{HNO}_{3}$ is an important contributor for the increased nitrate level in the cloud residuals (Schneider et al., 2017). Interestingly, we observed a decrease in nitrate intensity in all cloud residues except for dust type (Fig. 9), and a large size distribution of nitrate-containing cloud residues (Fig. S7) when compared with nonactivated particles. This result suggests that particle size, rather than nitrate content, plays a more important role in the activation of particles into cloud droplets.

Sulfate intensity enhancement was only observed in the OC cloud residues relative to both ambient and nonactivated particles. Although the in-cloud addition of sulfate can be produced from aqueous $\mathrm{Fe}$-catalyzed or oxidation by $\mathrm{H}_{2} \mathrm{O}_{2} / \mathrm{O}_{3}$ reactions (Harris et al., 2014), sulfate abundance was found in the Fe cloud residues relative to nonactivated particles, but no enhancement relative to ambient particles was found. Previous studies also showed that the mass or NF of sulfate-containing particles in the cloud residues changed between ambient and nonactivated particles (Drewnick et al., 2007; Twohy and Anderson, 2008; Schneider et al., 2017). However, the reason for these changes remains unclear.

The in-cloud process has been reported to be an important pathway for the production of amine particles (Rehbein et al., 2011; G. Zhang et al., 2012). In this study, no remarkable change in NF of the amine cloud residues was obtained relative to the ambient particles ( 0.2 vs. $0.2 \%$ ), as shown in Fig. 7. The absence of amine species in cloud residues may be partially affected by droplet evaporation in the GCVI (Bi et al., 2016). However, there was a high fraction of the amine cloud residuals when the southwesterly air mass prevailed, 
as discussed in Sect. 3.4. A lack of gas-phase amines may be the cause of the few amine particles detected in the ambient particles and cloud residues (Rehbein et al., 2011). An increase in NF of cloud residues was observed compared with nonactivated particles (5.2 vs. $0.1 \%$ ), as shown in Fig. 7. An increase of particle water content facilitates partitioning of gas-phase amine species into the aqueous phase when gasphase amines are present (Rehbein et al., 2011).

\section{Conclusions}

This study presented an in situ observation of individual cloud residues, nonactivated particles and ambient particles at a mountain site in southern China. The finding shows that the aged EC (49.3\%) and K-rich types $(33.9 \%)$ dominate the cloud residues in a remote area of China, followed by the $\mathrm{Fe}(4.1 \%)$, amine $(3.8 \%)$, Na-rich $(3.0 \%)$ and dust $(2.9 \%)$ types. The $\mathrm{OC}, \mathrm{Pb}$ and Other types contributed $0.1-2.3 \%$ to the total cloud residues. The observed change in NF of the cloud residue types, influenced by various air masses, highlights the important role of regional transportation in the observed cloud residual chemistry. Amine particles represented from 0.2 to $15.1 \%$ of the total cloud residues, dependent on the air mass history. Sulfate was found to be highly mixed with the K-rich, OC, aged $\mathrm{EC}, \mathrm{Pb}, \mathrm{Fe}$ and amine cloud residues, while nitrate was highly mixed with the Na-rich and dust cloud residues. Compared with nonactivated particles, nitrate intensity decreased in all cloud residues except for dust type, and sulfate intensity enhancement was only observed in the $\mathrm{OC}$ and Fe cloud residues.

Data availability. All the data can be obtained by contacting the corresponding author.

\section{The Supplement related to this article is available online at https://doi.org/10.5194/acp-17-8473-2017-supplement.}

Competing interests. The authors declare that they have no conflict of interest.

Acknowledgements. This work was supported by the National Key Research and Development Program of China (2017YFC0210104), the National Nature Science Foundation of China (grant nos. 91544101 and 41405131) and the Foundation for Leading Talents of the Guangdong Province Government. The authors thank Ji Ou from Shaoguan city Environmental Monitoring Center for the help during the study. We also acknowledge the NOAA Air Resources Laboratory (ARL) for the provision of the HYSPLIT transport and dispersion model and READY website (http://ready.arl.noaa.gov) used in this publication. This is a contribution from GIGCAS no. IS2406.
Edited by: James Allan

Reviewed by: Johannes Schneider and two anonymous referees

\section{References}

Angelino, S., Suess, D. T., and Prather, K. A.: Formation of aerosol particles from reactions of secondary and tertiary alkylamines: characterization by aerosol time-of-flight mass spectrometry, Environ. Sci. Technol., 35, 3130-3138, https://doi.org/10.1021/es0015444, 2001.

Atkinson, J. D., Murray, B. J., Woodhouse, M. T., Whale, T. F., Baustian, K. J., Carslaw, K. S., Dobbie, S., O'Sullivan, D., and Malkin, T. L.: The importance of feldspar for ice nucleation by mineral dust in mixed-phase clouds, Nature, 498, 355-358, 2013.

Bator, A. and Collett, J. L.: Cloud chemistry varies with drop size, J. Geophys. Res.-Atmos., 102, 28071-28078, 1997.

Bi, X., Zhang, G., Li, L., Wang, X., Li, M., Sheng, G., Fu, J., and Zhou, Z.: Mixing state of biomass burning particles by single particle aerosol mass spectrometer in the urban area of PRD, China, Atmos. Environ., 45, 3447-3453, https://doi.org/10.1016/j.atmosenv.2011.03.034, 2011.

Bi, X., Lin, Q., Peng, L., Zhang, G., Wang, X., Brechtel, F. J., Chen, D., Li, M., Peng, P. A., Sheng, G., and Zhou, Z.: In situ detection of the chemistry of individual fog droplet residues in the Pearl River Delta region, China, J. Geophys. Res.-Atmos., 121, 9105-9116, https://doi.org/10.1002/2016jd024886, 2016.

Berg, L. K., Berkowitz, C. M., Hubbe, J. M., Ogren, J. A., Hostetler, C. A., Ferrare, R. A., Hair, J. W., Dubey, M. K., Mazzoleni, C., and Andrews, E.: Overview of the cumulus humilis aerosol processing study, B. Am. Meteorol. Soc., 90, 1653-1667, https://doi.org/10.1175/2009BAMS2760.1, 2009.

Bond, T. C., Doherty, S. J., Fahey, D. W., Forster, P. M., Berntsen, T., DeAngelo, B. J., Flanner, M. G., Ghan, S., Kärcher, B., Koch, D., Kinne, S., Kondo, Y., Quinn, P. K., Sarofim, M. C., Schultz, M. G., Schulz, M., Venkataraman, C., Zhang, H., Zhang, S., Bellouin, N., Guttikunda, S. K., Hopke, P. K., Jacobson, M. Z., Kaiser, J. W., Klimont, Z., Lohmann, U., Schwarz, J. P., Shindell, D., Storelvmo, T., Warren, S. G., and Zender, C. S.: Bounding the role of black carbon in the climate system: a scientific assessment, J. Geophys. Res.Atmos., 118, 5380-5552, https://doi.org/10.1002/jgrd.50171, 2013.

Borys, R. D., Lowenthal, D. H., and Mitchell, D. L.: The relationships among cloud microphysics, chemistry, and precipitation rate in cold mountain clouds, Atmos. Environ., 34, 2593-2602, 2000.

Boucher, O., Randall, D., Artaxo, P., Bretherton, C., Feingold, G., Forster, P., Kerminen, V., Kondo, Y., Liao, H., Lohmann, U., Rasch, P., Satheesh, S., Sherwood, S., Stevens, B., and Zhang, X.: Clouds and Aerosols, in: Climate Change 2013: The Physical Science Basis. Contribution of Working Group I to the Fifth Assessment Report of the Intergovernmental Panel on Climate Change, edited by: Stocker, T. F., Qin, D., Plattner, G.-K., Tignor, M., Allen, S. K., Boschung, J., Nauels, A., Xia, Y., Bex, V., and Midgley, P. M., Cambridge University Press, Cambridge, UK and New York, NY, USA, 571-657, 2013.

Coggon, M. M., Sorooshian, A., Wang, Z., Craven, J. S., Metcalf, A. R., Lin, J. J., Nenes, A., Jonsson, H. H., Fla- 
gan, R. C., and Seinfeld, J. H.: Observations of continental biogenic impacts on marine aerosol and clouds off the coast of California, J. Geophys. Res.-Atmos., 119, 6724-6748, https://doi.org/10.1002/2013JD021228, 2014.

Collins, D. B., Ault, A. P., Moffet, R. C., Ruppel, M. J., CuadraRodriguez, L. A., Guasco, T. L., Corrigan, C. E., Pedler, B. E., Azam, F., Aluwihare, L. I., Bertram, T. H., Roberts, G. C., Grassian, V. H., and Bertram, T. H.: Impact of marine biogeochemistry on the chemical mixing state and cloud forming ability of nascent sea spray aerosol, J. Geophys. Res.-Atmos., 118, 85538565, 2013.

Cziczo, D. J., Murphy, D. M., Hudson, P. K., and Thomson, D. S.: Single particle measurements of the chemical composition of cirrus ice residue during CRYSTAL-FACE, J. Geophys. Res.Atmos., 109, D04201, https://doi.org/10.1029/2003JD004032, 2004.

Cziczo, D. J., Froyd, K. D., Hoose, C., Jensen, E. J., Diao, M., Zondlo, M. A., Smith, J. B., Twohy, C. H., and Murphy, D. M.: Clarifying the dominant sources and mechanisms of cirrus cloud formation, Science, 340, 1320-1324, https://doi.org/10.1126/science.1234145, 2013.

Deng, X., Wu, D., Shi, Y., Tang, H., Fan, S., Huang, H., Mao, W., and Ye, Y.: Comprehensive analysis of the macro-and microphysical characteristics of dense fog in the area south of the Nanling Mountains (in Chinese), J. Trop. Meteorol., 23, 424-434, 2007.

Drewnick, F., Schneider, J., Hings, S. S., Hock, N., Noone, K., Targino, A., Weimer, S., and Borrmann, S.: Measurement of ambient, interstitial, and residual aerosol particles on a mountaintop site in central Sweden using an aerosol mass spectrometer and a CVI, J. Atmos. Chem., 56, 1-20, https://doi.org/10.1007/s10874-006-9036-8, 2007.

Duncan, B. N., Martin, R. V., Staudt, A. C., Yevich, R., and Logan, J. A.: Interannual and seasonal variability of biomass burning emissions constrained by satellite observations, J. Geophys. Res.-Atmos., 108, 4100, https://doi.org/10.1029/2002jd002378, 2003.

Dusek, U., Frank, G., Hildebrandt, L., Curtius, J., Schneider, J., Walter, S., Chand, D., Drewnick, F., Hings, S., and Jung, D.: Size matters more than chemistry for cloud-nucleating ability of aerosol particles, Science, 312, 1375-1378, 2006.

Ervens, B. and Volkamer, R.: Glyoxal processing by aerosol multiphase chemistry: towards a kinetic modeling framework of secondary organic aerosol formation in aqueous particles, Atmos. Chem. Phys., 10, 8219-8244, https://doi.org/10.5194/acp10-8219-2010, 2010.

Facchini, M. C., Decesari, S., Rinaldi, M., Carbone, C., Finessi, E., Mircea, M., Fuzzi, S., Moretti, F., Tagliavini, E., and Ceburnis, D.: Important source of marine secondary organic aerosol from biogenic amines, Environ. Sci. Technol., 42, 9116-9121, https://doi.org/10.1021/es8018385, 2008.

Furukawa, T. and Takahashi, Y.: Oxalate metal complexes in aerosol particles: implications for the hygroscopicity of oxalatecontaining particles, Atmos. Chem. Phys., 11, 4289-4301, https://doi.org/10.5194/acp-11-4289-2011, 2011.

Hallberg, A., Ogren, J. A., Noone, K. J., Okada, K., Heintzenberg, J., and Svenningsson, I. B.: The influence of aerosol particle composition on cloud droplet formation, J. Atmos. Chem., 19, 153-171, https://doi.org/10.1007/978-94-011-0313-8_8,1994.
Hammer, E., Gysel, M., Roberts, G. C., Elias, T., Hofer, J., Hoyle, C. R., Bukowiecki, N., Dupont, J.-C., Burnet, F., Baltensperger, U., and Weingartner, E.: Size-dependent particle activation properties in fog during the ParisFog 2012/13 field campaign, Atmos. Chem. Phys., 14, 10517-10533, https://doi.org/10.5194/acp-1410517-2014, 2014.

Harris, E., Sinha, B., van Pinxteren, D., Tilgner, A., Fomba, K. W., Schneider, J., Roth, A., Gnauk, T., Fahlbusch, B., and Mertes, S.: Enhanced role of transition metal ion catalysis during in-cloud oxidation of $\mathrm{SO}_{2}$, Science, 340, 727-730, https://doi.org/10.1126/science.1230911, 2013.

Harris, E., Sinha, B., van Pinxteren, D., Schneider, J., Poulain, L., Collett, J., D’Anna, B., Fahlbusch, B., Foley, S., Fomba, K. W., George, C., Gnauk, T., Henning, S., Lee, T., Mertes, S., Roth, A., Stratmann, F., Borrmann, S., Hoppe, P., and Herrmann, H.: In-cloud sulfate addition to single particles resolved with sulfur isotope analysis during HCCT-2010, Atmos. Chem. Phys., 14, 4219-4235, https://doi.org/10.5194/acp-14-4219-2014, 2014.

Hayden, K. L., Macdonald, A. M., Gong, W., Toom-Sauntry, D., Anlauf, K. G., Leithead, A., Li, S. M., Leaitch, W. R., and Noone, K.: Cloud processing of nitrate, J. Geophys. Res.-Atmos., 113, D18201, https://doi.org/10.1029/2007jd009732, 2008.

Herckes, P., Valsaraj, K. T., and Collett, J. L., A review of observations of organic matter in fogs and clouds: origin, processing and fate, Atmos. Res., 132, 434-449, 2013.

Hiranuma, N., Brooks, S. D., Moffet, R. C., Glen, A., Laskin, A., Gilles, M. K., Liu, P., Macdonald, A. M., Strapp, J. W., and McFarquhar, G. M.: Chemical characterization of individual particles and residuals of cloud droplets and ice crystals collected on board research aircraft in the ISDAC 2008 study, J. Geophys. Res.-Atmos., 118, 6564-6579, 2013.

Hudson, P. K., Murphy, D. M., Cziczo, D. J., Thomson, D. S., de Gouw, J. A., Warneke, C., Holloway, J., Jost, H. J., and Hübler, G.: Biomass-burning particle measurements: characteristic composition and chemical processing, J. Geophys. Res.Atmos., 109, D23S27, https://doi.org/10.1029/2003JD004398, 2004.

Kamphus, M., Ettner-Mahl, M., Klimach, T., Drewnick, F., Keller, L., Cziczo, D. J., Mertes, S., Borrmann, S., and Curtius, J.: Chemical composition of ambient aerosol, ice residues and cloud droplet residues in mixed-phase clouds: single particle analysis during the Cloud and Aerosol Characterization Experiment (CLACE 6), Atmos. Chem. Phys., 10, 8077-8095, https://doi.org/10.5194/acp-10-8077-2010, 2010.

Kleinman, L. I., Daum, P. H., Lee, Y.-N., Lewis, E. R., Sedlacek III, A. J., Senum, G. I., Springston, S. R., Wang, J., Hubbe, J., Jayne, J., Min, Q., Yum, S. S., and Allen, G.: Aerosol concentration and size distribution measured below, in, and above cloud from the DOE G-1 during VOCALS-REx, Atmos. Chem. Phys., 12, $207-$ 223, https://doi.org/10.5194/acp-12-207-2012, 2012.

Laskin, A., Moffet, R. C., Gilles, M. K., Fast, J. D., Zaveri, R. A., Wang, B., Nigge, P., and Shutthanandan, J.: Tropospheric chemistry of internally mixed sea salt and organic particles: surprising reactivity of $\mathrm{NaCl}$ with weak organic acids, J. Geophys. Res.Atmos., 117, D15302, https://doi.org/10.1029/2012JD017743, 2012.

Lee, C. S. L., Li, X., Zhang, G., Peng, X., and Zhang, L.: Biomonitoring of trace metals in the atmosphere using moss (Hypnum 
plumaeforme) in the Nanling Mountains and the Pearl River Delta, Southern China, Atmos. Environ., 39, 397-407, 2005.

Li, L., Huang, Z., Dong, J., Li, M., Gao, W., Nian, H., Fu, Z., Zhang, G., Bi, X., and Cheng, P.: Real time bipolar time-of-flight mass spectrometer for analyzing single aerosol particles, Int. J. Mass Spectrom., 303, 118-124, https://doi.org/10.1016/j.ijms.2011.01.017, 2011.

Li, T., Wang, Y., Zhou, J., Wang, T., Ding, A., Nie, W., Xue, L., Wang, X., and Wang, W.: Evolution of trace elements in the planetary boundary layer in southern China: effects of dust storms and aerosol-cloud interaction, J. Geophys. Res.-Atmos., 122, 3492-3506, 2017.

Li, W., Li, P., Sun, G., Zhou, S., Yuan, Q., and Wang, W.: Cloud residues and interstitial aerosols from nonprecipitating clouds over an industrial and urban area in northern China, Atmos. Environ., 45, 2488-2495, https://doi.org/10.1016/j.atmosenv.2011.02.044, 2011.

Lohmann, U., Stier, P., Hoose, C., Ferrachat, S., Kloster, S., Roeckner, E., and Zhang, J.: Cloud microphysics and aerosol indirect effects in the global climate model ECHAM5-HAM, Atmos. Chem. Phys., 7, 3425-3446, https://doi.org/10.5194/acp-7-34252007, 2007.

Matsuki, A., Schwarzenboeck, A., Venzac, H., Laj, P., Crumeyrolle, S., and Gomes, L.: Cloud processing of mineral dust: direct comparison of cloud residual and clear sky particles during AMMA aircraft campaign in summer 2006, Atmos. Chem. Phys., 10, 1057-1069, https://doi.org/10.5194/acp-10-1057-2010, 2010.

McFiggans, G., Artaxo, P., Baltensperger, U., Coe, H., Facchini, M. C., Feingold, G., Fuzzi, S., Gysel, M., Laaksonen, A., Lohmann, U., Mentel, T. F., Murphy, D. M., O’Dowd, C. D., Snider, J. R., and Weingartner, E.: The effect of physical and chemical aerosol properties on warm cloud droplet activation, Atmos. Chem. Phys., 6, 2593-2649, https://doi.org/10.5194/acp-6-25932006, 2006.

McMeeking, G. R., Good, N., Petters, M. D., McFiggans, G., and Coe, H.: Influences on the fraction of hydrophobic and hydrophilic black carbon in the atmosphere, Atmos. Chem. Phys., 11, 5099-5112, https://doi.org/10.5194/acp-115099-2011, 2011.

Medina, J., Nenes, A., Sotiropoulou, R. E. P., Cottrell, L. D., Ziemba, L. D., Beckman, P. J., and Griffin, R. J.: Cloud condensation nuclei closure during the International Consortium for Atmospheric Research on Transport and Transformation 2004 campaign: effects of size-esolved composition, J. Geophys. Res.Atmos., 112, D10S31, https://doi.org/10.1029/2006JD007588, 2007.

Mertes, S., Lehmann, K., Nowak, A., Massling, A., and Wiedensohler, A.: Link between aerosol hygroscopic growth and dropletactivation observed for hill-capped clouds at connected flow conditions during FEBUKO, Atmos. Environ., 39, 4247-4256, 2005.

Moffet, R. C. and Prather, K. A.: In-situ measurements of the mixing state and optical properties of soot with implications for radiative forcing estimates, P. Natl. Acad. Sci. USA, 106, 11872 11877, https://doi.org/10.1073/pnas.0900040106, 2009.

Moffet, R. C., de Foy, B., Molina, L. T., Molina, M. J., and Prather, K. A.: Measurement of ambient aerosols in northern Mexico City by single particle mass spectrometry, Atmos. Chem. Phys., 8, 4499-4516, https://doi.org/10.5194/acp-8-4499-2008, 2008
Moore, K. F., Sherman, D. E., Reilly, J. E., and Collett, J. L.: Drop size-dependent chemical composition in clouds and fogs. Part I. Observations, Atmos. Environ., 38, 1389-1402, 2004.

Moteki, N., Adachi, K., Ohata, S., Yoshida, A., Harigaya, T., Koike, M., and Kondo, Y.: Anthropogenic iron oxide aerosols enhance atmospheric heating, Nat. Commun., 8, 15329, https://doi.org/10.1038/ncomms15329, 2017.

Pratt, K. A., DeMott, P. J., French, J. R., Wang, Z., Westphal, D. L., Heymsfield, A. J., Twohy, C. H., Prenni, A. J., and Prather, K. A.: In situ detection of biological particles in cloud ice-crystals, Nature Geosci., 2, 398-401, 2009a.

Pratt, K. A., Hatch, L. E., and Prather, K. A.: Seasonal volatility dependence of ambient particle phase amines, Environ. Sci. Technol., 43, 5276-5281, https://doi.org/10.1021/es803189n, 2009b.

Pratt, K. A., Heymsfield, A. J., Twohy, C. H., Murphy, S. M., DeMott, P. J., Hudson, J. G., Subramanian, R., Wang, Z., Seinfeld, J. H., and Prather, K. A.: In situ chemical characterization of aged biomass-burning aerosols impacting cold wave clouds, J. Atmos. Sci., 67, 2451-2468, https://doi.org/10.1175/2010jas3330.1, 2010a.

Pratt, K. A., Twohy, C. H., Murphy, S. M., Moffet, R. C., Heymsfield, A. J., Gaston, C. J., DeMott, P. J., Field, P. R., Henn, T. R., Rogers, D. C., Gilles, M. K., Seinfeld, J. H., and Prather, K. A.: Observation of playa salts as nuclei in orographic wave clouds, J. Geophys. Res.-Atmos., 115, D15301, https://doi.org/10.1029/2009JD013606, 2010b.

Pratt, K. A., Murphy, S. M., Subramanian, R., DeMott, P. J., Kok, G. L., Campos, T., Rogers, D. C., Prenni, A. J., Heymsfield, A. J., Seinfeld, J. H., and Prather, K. A.: Flight-based chemical characterization of biomass burning aerosols within two prescribed burn smoke plumes, Atmos. Chem. Phys., 11, 1254912565, https://doi.org/10.5194/acp-11-12549-2011, 2011.

Qin, X., Bhave, P. V., and Prather, K. A.: Comparison of two methods for obtaining quantitative mass concentrations from aerosol time-of-flight mass spectrometry measurements, Anal. Chem., 78, 6169-6178, https://doi.org/10.1021/ac060395q, 2006.

Rehbein, P. J., Jeong, C. H., McGuire, M. L., Yao, X., Corbin, J. C., and Evans, G. J.: Cloud and fog processing enhanced gas-toparticle partitioning of trimethylamine, Environ. Sci. Technol. 45, 4346-4352, https://doi.org/10.1021/es1042113, 2011.

Rosenfeld, D., Lohmann, U., Raga, G. B., O’Dowd, C. D., Kulmala, M., Fuzzi, S., Reissell, A., and Andreae, M. O.: Flood or drought: how do aerosols affect precipitation?, Science, 321, 1309-1313, https://doi.org/10.1126/science.1160606, 2008.

Roth, A., Schneider, J., Klimach, T., Mertes, S., van Pinxteren, D., Herrmann, H., and Borrmann, S.: Aerosol properties, source identification, and cloud processing in orographic clouds measured by single particle mass spectrometry on a central European mountain site during HCCT-2010, Atmos. Chem. Phys., 16, 505524, https://doi.org/10.5194/acp-16-505-2016, 2016.

Schneider, J., Mertes, S., van Pinxteren, D., Herrmann, H., and Borrmann, S.: Uptake of nitric acid, ammonia, and organics in orographic clouds: mass spectrometric analyses of droplet residual and interstitial aerosol particles, Atmos. Chem. Phys., 17, 15711593, https://doi.org/10.5194/acp-17-1571-2017, 2017.

Seinfeld, J. H., Bretherton, C., Carslaw, K. S., Coe, H., DeMott, P. J., Dunlea, E. J., Feingold, G., Ghan, S., Guenther, A. B., and Kahn, R.: Improving our fundamental understanding of the role of aerosol-cloud interactions in the 
climate system, P. Natl. Acad. Sci. USA, 113, 5781-5790, https://doi.org/10.1073/pnas.1514043113, 2016.

Sellegri, K., Laj, P., Dupuy, R., Legrand, M., Preunkert, S., and Putaud, J. P.: Size-dependent scavenging efficiencies of multicomponent atmospheric aerosols in clouds, J. Geophys. Res.-Atmos., 108, 4334, https://doi.org/10.1029/2002JD002749, 2003a.

Sellegri, K., Laj, P., Marinoni, A., Dupuy, R., Legrand, M., and Preunkert, S.: Contribution of gaseous and particulate species to droplet solute composition at the Puy de Dôme, France, Atmos. Chem. Phys., 3, 1509-1522, https://doi.org/10.5194/acp-3-15092003, 2003b.

Shingler, T., Dey, S., Sorooshian, A., Brechtel, F. J., Wang, Z., Metcalf, A., Coggon, M., Mülmenstädt, J., Russell, L. M., Jonsson, H. H., and Seinfeld, J. H.: Characterisation and airborne deployment of a new counterflow virtual impactor inlet, Atmos. Meas. Tech., 5, 1259-1269, https://doi.org/10.5194/amt-5-1259-2012, 2012.

Sjogren, S., Gysel, M., Weingartner, E., Baltensperger, U., Cubison, M. J., Coe, H., Zardini, A. A., Marcolli, C., Krieger, U. K., and Peter, T.: Hygroscopic growth and water uptake kinetics of two-phase aerosol particles consisting of ammonium sulfate, adipic and humic acid mixtures, J. Aerosol Sci., 38, 157-171, 2007.

Song, X. H., Hopke, P. K., Fergenson, D. P., and Prather, K. A.: Classification of single particles analyzed by ATOFMS using an artificial neural network, ART-2A, Anal. Chem., 71, 860-865, https://doi.org/10.1021/ac9809682, 1999.

Sorooshian, A., Ng, N. L., Chan, A. W. H., Feingold, G., Flagan, R. C., and Seinfeld, J. H.: Particulate organic acids and overall water-soluble aerosol composition measurements from the 2006 Gulf of Mexico Atmospheric Composition and Climate Study (GoMACCS), J. Geophys. Res.-Atmos., 112, D13201, https://doi.org/10.1029/2007JD008537, 2007a.

Sorooshian, A., Lu, M. L., Brechtel, F. J., Jonsson, H., Feingold, G., Flagan, R. C., and Seinfeld, J. H.: On the source of organic acid aerosol layers above clouds, Environ. Sci. Technol., 41, 46474654, https://doi.org/10.1021/es0630442, $2007 \mathrm{~b}$.

Stier, P., Feichter, J., Kinne, S., Kloster, S., Vignati, E., Wilson, J., Ganzeveld, L., Tegen, I., Werner, M., Balkanski, Y., Schulz, M., Boucher, O., Minikin, A., and Petzold, A.: The aerosol-climate model ECHAM5-HAM, Atmos. Chem. Phys., 5, 1125-1156, https://doi.org/10.5194/acp-5-1125-2005, 2005.

Svenningsson, B., Rissler, J., Swietlicki, E., Mircea, M., Bilde, M., Facchini, M. C., Decesari, S., Fuzzi, S., Zhou, J., Mønster, J., and Rosenørn, T.: Hygroscopic growth and critical supersaturations for mixed aerosol particles of inorganic and organic compounds of atmospheric relevance, Atmos. Chem. Phys., 6, 1937-1952, https://doi.org/10.5194/acp-6-1937-2006, 2006.

Tang, M., Cziczo, D. J., and Grassian, V. H.: Interactions of water with mineral dust aerosol: water adsorption, hygroscopicity, cloud condensation, and ice nucleation, Chem. Rev., 116, 42054259, 2016.

Targino, A. C., Krejci, R., Noone, K. J., and Glantz, P.: Single particle analysis of ice crystal residuals observed in orographic wave clouds over Scandinavia during INTACC experiment, Atmos. Chem. Phys., 6, 1977-1990, https://doi.org/10.5194/acp-61977-2006, 2006.
Tsai, J. H., Lin, K. H., Chen, C. Y., Ding, J. Y., Choa, C. G., and Chiang, H. L.: Chemical constituents in particulate emissions from an integrated iron and steel facility, J. Hazard. Mater., 147, 111119, 2007.

Twohy, C. H. and Anderson, J. R.: Droplet nuclei in nonprecipitating clouds: composition and size matter. Environ. Res. Lett., 3, 045002, https://doi.org/10.1088/1748-9326/3/4/045002, 2008.

Twohy, C. H. and Poellot, M. R.: Chemical characteristics of ice residual nuclei in anvil cirrus clouds: evidence for homogeneous and heterogeneous ice formation, Atmos. Chem. Phys., 5, 22892297, https://doi.org/10.5194/acp-5-2289-2005, 2005.

Twohy, C. H., Kreidenweis, S. M., Eidhammer, T., Browell, E. V., Heymsfield, A. J., Bansemer, A. R., Anderson, B. E., Chen, G., Ismail, S., DeMott, P. J., and Van Den Heever, S. C.: Saharan dust particles nucleate droplets in eastern Atlantic clouds, Geophys. Res. Lett., 36, L01807, https://doi.org/10.1029/2008GL035846, 2009.

Wang, H., An, J., Shen, L., Zhu, B., Xia, L., Duan, Q., and Zou, J.: Mixing state of ambient aerosols in Nanjing city by single particle mass spectrometry, Atmos. Environ., 132, 123-132, 2016.

Wang, Y., Guo, J., Wang, T., Ding, A., Gao, J., Zhou, Y., Collett, J. L., and Wang, W.: Influence of regional pollution and sandstorms on the chemical composition of cloud/fog at the summit of Mt. Taishan in northern China, Atmos. Res., 99, 434-442, https://doi.org/10.1016/j.atmosres.2010.11.010, 2011.

Wiedensohler, A., Cheng, Y. F., Nowak, A., Wehner, B., Achtert, P., Berghof, M., Birmili, W., Wu, Z. J., Hu, M., Zhu, T., Takegawa, N., Kita, K., Kondo, Y., Lou, S. R., Hofzumahaus, A., Holland, F., Wahner, A., Gunthe, S. S., Rose, D., Su, H., and Takegawa, N.: Rapid aerosol particle growth and increase of cloud condensation nucleus activity by secondary aerosol formation and condensation: a case study for regional air pollution in northeastern China, J. Geophys. Res.-Atmos., 114, D00G08, https://doi.org/10.1029/2008JD010884, 2009.

Wise, M. E., Surratt, J. D., Curtis, D. B., Shilling, J. E., and Tolbert, M. A. Hygroscopic growth of ammonium sulfate/dicarboxylic acids, J. Geophys. Res.-Atmos., 108, 4638, https://doi.org/10.1029/2003JD003775, 2003.

Zelenyuk, A., Imre, D., Earle, M., Easter, R., Korolev, A., Leaitch, R., Liu, P., Macdonald, A. M., Ovchinnikov, M., and Strapp, W.: In situ characterization of cloud condensation nuclei, interstitial, and background particles using the Single Particle Mass Spectrometer, SPLAT II, Anal. Chem., 82, 7943-7951, https://doi.org/10.1021/ac1013892, 2010.

Zhang, G., Bi, X., Chan, L. Y., Li, L., Wang, X., Feng, J., Sheng, G., Fu, J., Li, M., and Zhou, Z.: Enhanced trimethylamine-containing particles during fog events detected by single particle aerosol mass spectrometry in urban Guangzhou, China, Atmos. Environ., 55, 121-126, https://doi.org/10.1016/j.atmosenv.2012.03.038, 2012

Zhang, G., Bi, X., Li, L., Chan, L. Y., Li, M., Wang, X., Sheng, G., Fu, J., and Zhou, Z.: Mixing state of individual submicron carbon-containing particles during spring and fall seasons in urban Guangzhou, China: a case study, Atmos. Chem. Phys., 13, 4723-4735, https://doi.org/10.5194/acp-13-4723-2013, 2013.

Zhang, G., Bi, X., Lou, S., Li, L., Wang, H., Wang, X., Zhou, Z., Sheng, G., Fu, J., and Chen, C.: Source and mixing state of iron- 
containing particles in Shanghai by individual particle analysis, Chemosphere, 95, 9-16, 2014.

Zhang, R. Y., Khalizov, A. F., Pagels, J., Zhang, D., Xue, H., and McMurry, P. H.: Variability in morphology, hygroscopicity, and optical properties of soot aerosols during atmospheric processing, P. Natl. Acad. Sci. USA, 105, 10291-10296, https://doi.org/10.1073/pnas.0804860105, 2008.

Zhang, X. Y., Wang, Y. Q., Niu, T., Zhang, X. C., Gong, S. L., Zhang, Y. M., and Sun, J. Y.: Atmospheric aerosol compositions in China: spatial/temporal variability, chemical signature, regional haze distribution and comparisons with global aerosols, Atmos. Chem. Phys., 12, 779-799, https://doi.org/10.5194/acp12-779-2012, 2012.
Zhang, Y. P., Wang, X. F., Chen, H., Yang, X., Chen, J. M., and Allen, J. O.: Source apportionment of lead-containing aerosol particles in Shanghai using single particle mass spectrometry, Chemosphere, 74, 501-507, 2009. 